\title{
上肢静脉管の年 令的変化
}

\author{
日本医科大学解剖学教室 (指導 金子丑之助教授) \\ 佐伯梧郎 \\ Goro Saheki
}

\section{緒言}

動脉管の計測並びに年令的変化に関する研究は，内 外多数の学者に上り行われているが，静脉管特に四肢 静脉管の計測または組織学的研究は著者の賽聞のため 欧米に衿てて余り多く見られない。本邦では山下 が上肢の皮静脉 16 部位, 深静脉 62 部位にわたり系 統的に静脉管周囲径及び厚径を測定して左右, 性別, 年令々の関係索詳細に報告しているが，組織学的な面 に注ふれていない。渡辺 ${ }^{4) 八 9)}$, 西丸, 西田 ${ }^{12)}$, 山本 ${ }^{11}$, 石田 ${ }^{15)}$, 藤田 $\left.{ }^{13}\right)$ の静脉壁弾性線維, 格子線維, 筋量な ど組織学的研究が可られるが，多数部位にわたり，乙 かも多数例の年令的変化の追求はなされていない。

ここに怙いて著者は，皮静脉 18 個所（18部位）深 静脉 20 個所 (40 部位)について内径, 壁厚, 内・中・ 外膜 3 層の厚径を計測すると共に，各層の組織学的変 化を追求し, 先人の研究と比較してや」見るべき結果 を得たので、こ」に報告し御批判を乞うことにする。

な㧍，静脉管各部の名称は恩師金子教授の日本人体 解剖学に上る。

\section{I. 研究資料及ひ研究方法}

本研究に使用した資料は，当教室に招いて一定条件 下汇貯蔵された 19 才より 76 才までの本邦成人屍 45 体（男 35，女 10）である。人生期別分類を表 1 亿揭 げる。

表 1. 研究資料の性別人生期別分布

\begin{tabular}{|c|c|c|c|c|c|c|c|c|}
\hline $\begin{array}{l}\text { 人生 } \\
\text { 期別 } \\
\text { 性別 }\end{array}$ & $\begin{array}{l}\text { 青 } \\
\text { 年 } \\
\text { 期 }\end{array}$ & $\begin{array}{c}\text { 第一 } \\
\text { 熟期 }\end{array}$ & 第二 & $\begin{array}{l}\text { 第三 } \\
\text { 成熱期 }\end{array}$ & 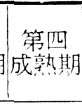 & $\begin{array}{l}\text { 第一 } \\
\text { 老年期 }\end{array}$ & $\begin{array}{l}\text { 第二 } \\
\text { 老年期 }\end{array}$ & $\begin{array}{l}\text { 合 } \\
\text { 計 }\end{array}$ \\
\hline 男 & 1 & 12 & 5 & 5 & 4 & 4 & 4 & 35 \\
\hline 女 & 0 & 0 & 1 & 2 & 2 & 1 & 4 & 10 \\
\hline 計 & 1 & 12 & 6 & 7 & 6 & 5 & 8 & 45 \\
\hline
\end{tabular}

死亡揨断畫により，死因を分類すると，肺結核 9 ,

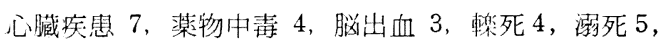
気管支肺炎 2 , 槛死 3 , 胃癌 1 , 脳軟化 1 , 死因不明 6 である

資料採取にあたり，静脉は動脉に比し破損しやすき ため立分な注意を払い，力つ肉眼上病的变化及び損傷
なきもの剪刀をもつて皮下 18 個所, 深部 20 個 所, 計 38 個所 58 部位に括いて血管走行に対し直角に 3〜8 $\mathrm{mm}$ の長さに環状に切取り, 直ちに $10 \%$ ホル マリン液中に 24 洔間固定後, 24 時間水洗渐強アル コールで脱承，セ口イジン包埋を行い $15, \mu$ 切片を作 り，ヘマトキシリン。エオジン及びワイゲルト弾性線 維染色を施し，かつ無染色褾本を補助とした。計測は 小血管及ざ比較的円形汇近い静脉柱ミクロメーターを 用いて内径・壁厚(内・中・外膜) 計測し，不正形及 び比較的大なる血管は引延器により挔大投影後、キル ビメーターに上り内周囲径を計り換算し，厚計はミク ロメーターに上り計測, 同時に組織学的微細構造を併 せ觀察した。各例の集計にあたり，男子の計測值を主 とし女子は男子值の下段に併記し参考に止为ることに した。しかし組織学的な観察については男女を通じて 述べることにする。な招皮下及び深部に分けて記載す ベきであるが，今回は両者を併せ抜轨して記载した。

\section{II. 成}

\section{績}

\section{A. 上肢静脉管内径の計測}

\section{1. 内径の平均值}

直径の計測にあたり静脉管に沏いては外膜の破損が 生じやすく, 反之内膜の変化少きため, 一方の内膜内 縁上り対側内膜内縁にいたる内径数個所の平均值をる つてその部位の值とした（大静脉及び不正形の静脉江 内周上り換算)。日本人上肢皮下及び深静脉内径の平均 值及び最大, 最小值を表 2 亿揭げる。この表により， 上肢静脉管の内径は男女両性を通じ皮下深部共 1 2 の例外を除き，末梢上り中心に進むにしたがい增大寸 る傾向があり，山下の報告とよく一致している。

\section{2. 年令亡上肢静脉管内径との関係}

人生期別上肢静脉管内径の平均値を表 3 亿揭げる。

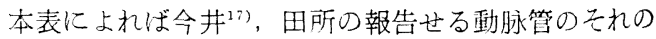
如き確然たる年令的関係を認为得ず。また山下の深静 脉は不明なるも皮静脉の周径は50才頃まて渐增し以 後減ずる傾向にあるとの報告に比較し，著者の数值は 一部同様なるも全体的には明らかでなく，むしろ深静 脉に打いて年令と共に增大する傾向にあるように思わ 
表 2. 上肢静脉管の内径・壁厚 ·厚度率の平均値 上段 今 下段（）ㅇ

\begin{tabular}{|c|c|c|c|c|c|c|c|c|}
\hline \multirow{2}{*}{ No. } & & \multirow{2}{*}{ 計測 部位 } & & \multicolumn{2}{|c|}{ 内 径 $(\mu)$} & \multicolumn{2}{|c|}{ 壁 厚 $\quad(\mu)$} & \multirow{2}{*}{$\frac{\sqrt{9} \text { 度婆 }}{\mathrm{M}}$} \\
\hline & & & & $\mathrm{M}$ & 最大值～最小值 & M & 最大値〜最小値 & \\
\hline 1 & $\begin{array}{c}\text { 橈 側 皮 静 脉 } \\
\text { (I) }\end{array}$ & $\begin{array}{l}\text { 腋窩静脉:こは } \\
\text { いる前 } 1 \mathrm{~cm}\end{array}$ & $\begin{array}{c}31 \\
(7)\end{array}$ & $\begin{array}{c}1,640.71 \\
(1,786.70) \\
\end{array}$ & $\begin{array}{cc}1,990.34- & 663.70 \\
(2,082.76- & 154.41)\end{array}$ & $\begin{array}{c}156.65 \\
(140.71)\end{array}$ & $\begin{array}{c}302.13-32.00 \\
(134.40-60.80)\end{array}$ & $\begin{array}{r}9.54 \\
(7.87)\end{array}$ \\
\hline 2 & (III) & $\begin{array}{l}\text { 外側上顆の上 } \\
3 \mathrm{~cm}\end{array}$ & $\begin{array}{l}31 \\
(6)\end{array}$ & $\begin{array}{c}1,635.63 \\
(1,770.45)\end{array}$ & $\begin{array}{c}2,156.20- \\
(2,669.92-1,031.27)\end{array}$ & $\begin{array}{r}248.58 \\
(227.11) \\
\end{array}$ & $\begin{array}{c}430.11-93.60 \\
(435.32-110.81)\end{array}$ & $\begin{array}{c}15.19 \\
(12.83)\end{array}$ \\
\hline 3 & (IV) & $\begin{array}{l}\text { 外側上顆の下 } \\
3 \mathrm{~cm}\end{array}$ & $\begin{array}{c}30 \\
(5)\end{array}$ & $\begin{array}{c}1,714.41 \\
(1,896.94)\end{array}$ & $\left.\begin{array}{cc}3,673.77- & 370.14 \\
(3,216.40-1,372.68)\end{array}\right)$ & $\begin{array}{c}272.31 \\
(200.14)\end{array}$ & $\begin{array}{c}554.05-128.00 \\
(237.45-96.00) \\
\end{array}$ & $\begin{array}{c}15.09 \\
(16.90)\end{array}$ \\
\hline 4 & $\stackrel{\prime \prime}{(V I)}$ & $\begin{array}{l}\text { 橈骨茎状突起 } \\
\text { の上 } 1 \mathrm{~cm}\end{array}$ & $\begin{array}{c}30 \\
(5)\end{array}$ & $\begin{array}{c}1,331.54 \\
(1,100.99) \\
\end{array}$ & $\begin{array}{cc}2,969.99- & 191.47 \\
(1,832.15- & 164.33)\end{array}$ & $\begin{array}{c}278.21 \\
(307.10)\end{array}$ & $\begin{array}{c}474.90-128.00 \\
(379.92-237.45)\end{array}$ & $\begin{array}{c}20.89 \\
(26.88)\end{array}$ \\
\hline 5 & $\begin{array}{c}\text { 尺 側 皮 静 脉 } \\
\text { (I) }\end{array}$ & $\begin{array}{l}\text { 上腕静脉には } \\
\text { いる前 } 1 \mathrm{~cm}\end{array}$ & $\begin{array}{c}30 \\
(6)\end{array}$ & $\begin{array}{c}2,162.26 \\
(2,154.80)\end{array}$ & $\begin{array}{c}4,363,94- \\
(3,197.58-1,291.10)\end{array}$ & $\begin{array}{c}221.71 \\
(228.81)\end{array}$ & $\begin{array}{c}403.04-98.52 \\
(324.70-67.20) \\
\end{array}$ & $\begin{array}{c}10.25 \\
(10.60)\end{array}$ \\
\hline 6 & (II) & $\begin{array}{l}\text { 上腕筋膜を入 } \\
\text { る所 }\end{array}$ & $\begin{array}{c}31 \\
(8)\end{array}$ & $\begin{array}{c}2,366.82 \\
(2,669.32)\end{array}$ & $\begin{array}{cc}5,650.40- & 564.56 \\
(4,845.49-1,732.13)\end{array}$ & $\begin{array}{c}251.16 \\
(237.62) \\
\end{array}$ & $\begin{array}{c}483-00-89.60 \\
(306.20-96.40)\end{array}$ & $\begin{array}{c}11.03 \\
(8.90) \\
\end{array}$ \\
\hline 7 & (III) & $\begin{array}{l}\text { 外側上顆の下 } \\
3 \mathrm{~cm}\end{array}$ & $\begin{array}{c}23 \\
(8)\end{array}$ & & $\begin{array}{cc}3,236.08- & 187.14 \\
(6,610.61- & 672.12)\end{array}$ & $\begin{array}{c}272.41 \\
(207.81)\end{array}$ & $\begin{array}{c}348.96-80.00 \\
(316.60-63.60)\end{array}$ & $\begin{array}{c}15.31 \\
(11.33)\end{array}$ \\
\hline 8 & $(\mathrm{~V})$ & $\begin{array}{l}\text { 尺骨茎状突起 } \\
\text { の上 } 1 \mathrm{~cm}\end{array}$ & $\begin{array}{c}24 \\
(6)\end{array}$ & $\begin{array}{r}1,438,82 \\
(\quad 666.46) \\
\end{array}$ & $\begin{array}{cc}4,292.25- & 417.43 \\
(1,460.80- & 166.05)\end{array}$ & $\begin{array}{c}225.25 \\
(161.20)\end{array}$ & $\begin{array}{c}395.75-64.00 \\
(205.79-94.98) \\
\end{array}$ & $\begin{array}{c}15.66 \\
(24.18)\end{array}$ \\
\hline 9 & 肘正中皮静脉 & 中 央 部 & $\begin{array}{c}32 \\
(8)\end{array}$ & $\begin{array}{c}1,829.62 \\
(2,663.56)\end{array}$ & $\begin{array}{cc}4,416.27- & 501.01 \\
(4,482.59- & 249.63)\end{array}$ & $\begin{array}{c}234.96 \\
(271.83)\end{array}$ & $\begin{array}{r}47.90-82.69 \\
(362.25-80.00) \\
\end{array}$ & $\begin{array}{c}12.84 \\
(10.17)\end{array}$ \\
\hline 10 & 前腕正中皮静脉 & 中 央 部 & $\begin{array}{c}28 \\
(5)\end{array}$ & $\begin{array}{c}1,068.89 \\
(1,022.08) \\
\end{array}$ & $\begin{array}{rr}3,122.54- & 182.82 \\
(1,814.01- & 295.03)\end{array}$ & $\begin{array}{r}222.78 \\
(168.57) \\
\end{array}$ & $\begin{array}{c}4+3.24-73.60 \\
(237.45-70.40) \\
\end{array}$ & $\begin{array}{c}20.84 \\
(16.48) \\
\end{array}$ \\
\hline 11 & 背側中手静脉 & $\begin{array}{l}\text { (12) との接続 } \\
\text { する中央部 }\end{array}$ & $\begin{array}{c}24 \\
(5)\end{array}$ & $\begin{array}{l}928.42 \\
(\quad 852.48) \\
\end{array}$ & $\begin{array}{cc}2,338.32- & 323.04 \\
(1,329.92- & 229.51)\end{array}$ & $\begin{array}{c}204.89 \\
(186.79)\end{array}$ & $\begin{array}{r}365.09-96.00 \\
(237.45-126.64) \\
\end{array}$ & $\begin{array}{c}22.89 \\
(21.91)\end{array}$ \\
\hline 12 & 固有背側指静脉 & $\begin{array}{l}(\mathrm{II} \sim \mathrm{III})- \\
\text { 節の中央部 }\end{array}$ & $\begin{array}{c}20 \\
(4)\end{array}$ & $\begin{array}{l}709.59 \\
(\quad 497.11)\end{array}$ & 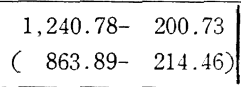 & $\begin{array}{c}163.10 \\
(133.38)\end{array}$ & $\begin{array}{c}262.38-64.00 \\
(237.45-60.80)\end{array}$ & $\begin{array}{c}23.67 \\
(26.83)\end{array}$ \\
\hline 13 & $\begin{array}{c}\text { 上腕動脉伴行静脉 } \\
\text { (上) }\end{array}$ & 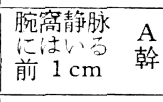 & $\begin{array}{c}28 \\
(5)\end{array}$ & $\begin{array}{c}4,447.16 \\
(3,867.28)\end{array}$ & $\begin{array}{r}8,973.39-1,944.47 \\
(5,726.83-891.32)\end{array}$ & $\begin{array}{c}200.47 \\
(145.61)\end{array}$ & $\begin{array}{c}395.75-80.00 \\
(204.47-83.20) \\
\end{array}$ & $\begin{array}{r}4.53 \\
(3.77) \\
\end{array}$ \\
\hline 14 & (上) & $\begin{array}{l}\mathrm{B} \\
\text { 幹 }\end{array}$ & $\begin{array}{c}16 \\
(0)\end{array}$ & $2,451.13$ & $4,642.95-1,480.32$ & 181.32 & $237.45-110.81$ & 9.69 \\
\hline 15 & $\begin{array}{c}\prime \prime \\
(下)\end{array}$ & 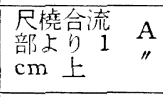 & $\begin{array}{c}29 \\
(4)\end{array}$ & $\begin{array}{c}2,282.79 \\
(2,008.16)\end{array}$ & $\begin{array}{rr}4,341.05- & 375.89 \\
(3,619.62- & 283.53)\end{array}$ & $\begin{array}{r}161.95 \\
(96.01) \\
\end{array}$ & $\begin{array}{c}237.45-79.15 \\
(110.81-79.15) \\
\end{array}$ & $\begin{array}{r}7.09 \\
(4.74) \\
\end{array}$ \\
\hline 16 & $\begin{array}{l}\prime \prime \\
(下)\end{array}$ & $\begin{array}{l}\text { B } \\
\prime \prime\end{array}$ & $\begin{array}{c}14 \\
(0)\end{array}$ & $2,231.95$ & $3,468.89-259.13$ & 148.07 & $256.48-70.10$ & 7.46 \\
\hline 17 & 上腕深動脉伴行静脉 & $\begin{array}{l}\text { 上腕静脉 } \\
\text { に前 } \\
1 \mathrm{~cm}\end{array}$ & $\begin{array}{c}22 \\
(4)\end{array}$ & $\begin{array}{c}2,382.78 \\
(1,751.13) \\
\end{array}$ & 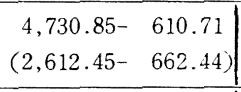 & $\begin{array}{r}114.01 \\
(51.58) \\
\end{array}$ & $\begin{array}{r}221.62-35.20 \\
(63.32-47.49) \\
\end{array}$ & $\begin{array}{r}4.82 \\
(3.02) \\
\end{array}$ \\
\hline 18 & " & $\begin{array}{l}\mathrm{B} \\
\prime \prime\end{array}$ & $\begin{array}{c}15 \\
(1)\end{array}$ & $\begin{array}{c}2,098.98 \\
(\quad 491.03)\end{array}$ & $\begin{array}{l}5,002.49-1,215.68 \\
(\quad 491.03)\end{array}$ & $\begin{array}{c}76.66 \\
(47.49)\end{array}$ & $\begin{array}{l}139.35-38.40 \\
(47.49)\end{array}$ & $\begin{array}{l}3.64 \\
(9.67)\end{array}$ \\
\hline 19 & $\begin{array}{c}\text { 橈骨動脉 伴行静脉 } \\
\text { (上) }\end{array}$ & $\begin{array}{l}\text { 上腕静脉 } \mathrm{A} \\
\text { 前Wる } \\
\text { 前 } 1 \mathrm{~cm}\end{array}$ & $\begin{array}{c}27 \\
(5)\end{array}$ & $\begin{array}{c}1,191.36 \\
(1,321.79)\end{array}$ & $\begin{array}{cc}2,258.45- & 183.59 \\
(2,146.12- & 463.33)\end{array}$ & $\begin{array}{r}143.90 \\
(138.47) \\
\end{array}$ & $\begin{array}{c}301.62-35.20 \\
(270.11-70.40) \\
\end{array}$ & $\begin{array}{c}12.07 \\
(10.47) \\
\end{array}$ \\
\hline 20 & (上) & $\underset{n}{\mathrm{~B}}$ & $\begin{array}{c}17 \\
(1)\end{array}$ & $\begin{array}{l}901.26 \\
(\quad 773.54) \\
\end{array}$ & $\begin{array}{r}1,532.58-273.51 \\
(\quad 773.54)\end{array}$ & $\begin{array}{r}105.68 \\
(73.60) \\
\end{array}$ & $\begin{array}{l}158.30-44.20 \\
(73.60)\end{array}$ & $\begin{array}{c}11.47 \\
(10.50) \\
\end{array}$ \\
\hline 21 & $\stackrel{\prime \prime}{(\text { (下) }}$ & $\begin{array}{l}\text { 起始部より } \\
1 \mathrm{~cm} \text { 上 }\end{array}$ & $\begin{array}{c}27 \\
(5)\end{array}$ & $\begin{array}{l}787.75 \\
(883.29)\end{array}$ & $\begin{array}{cc}1,672.64- & 218.54 \\
(1,845.15- & 535.70)\end{array}$ & $\begin{array}{c}108.86 \\
(76.16)\end{array}$ & $\begin{array}{c}332.43-32.00 \\
(112.00-41.60)\end{array}$ & $\begin{array}{c}13.82 \\
(8.62)\end{array}$ \\
\hline
\end{tabular}




\begin{tabular}{|c|c|c|c|c|c|c|c|c|c|}
\hline 22 & $\begin{array}{l}\prime \prime \\
(\text { (下) }\end{array}$ & ' & $\begin{array}{c}B \\
\text { 幹 }\end{array}$ & $\begin{array}{c}19 \\
(3)\end{array}$ & $\begin{array}{l}837.86 \\
(\quad 662.06)\end{array}$ & $\begin{array}{cc}2,280.13- & 168.38 \\
(1,088.94- & 345.44)\end{array}$ & $\begin{array}{c}96.03 \\
(63.40)\end{array}$ & $\begin{array}{c}189.96-32.00 \\
(81.20-35.20)\end{array}$ & $\begin{array}{r}10.27 \\
(9.57)\end{array}$ \\
\hline 23 & $\begin{array}{c}\text { 尺骨動脉伴行静脉 } \\
\text { (上) }\end{array}$ & $\begin{array}{l}\text { 上腕青争脉 } \\
\text { 忙方 } \\
\text { 前 } 1 \mathrm{~cm}\end{array}$ & $\underset{\prime \prime}{\mathrm{A}}$ & $\begin{array}{l}27 \\
(4)\end{array}$ & $\begin{array}{c}1,696.94 \\
(1,933.39)\end{array}$ & $\left.\begin{array}{cc}3,151.28- & 590.25 \\
(2,743.02-1,223.54\end{array}\right)$ & $\begin{array}{c}141.92 \\
(82.61)\end{array}$ & $\begin{array}{c}284.94-41.60 \\
(150.40-41.60)\end{array}$ & $\begin{array}{r}8.36 \\
(4.27) \\
\end{array}$ \\
\hline 24 & (上) & " & $\begin{array}{l}\text { B } \\
\prime \prime\end{array}$ & $\begin{array}{l}17 \\
(2)\end{array}$ & $\begin{array}{l}794.94 \\
720.16)\end{array}$ & 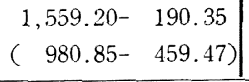 & $\begin{array}{r}110.92 \\
(73.60) \\
\end{array}$ & $\begin{array}{c}221.62-57.60 \\
(105.60-41.60)\end{array}$ & $\begin{array}{c}13.95 \\
(10.22)\end{array}$ \\
\hline 25 & $($ (下) & $\begin{array}{l}\text { 起始部よ } \\
\text { り } 1 \mathrm{~cm} \text { 上 }\end{array}$ & ${ }^{\mathrm{A}}$ & $\begin{array}{l}27 \\
(4)\end{array}$ & $\begin{array}{l}733.69 \\
538.58)\end{array}$ & $\begin{array}{rr}3,065.20- & 191.47 \\
(3,919.18- & 433.56\end{array}$ & $\begin{array}{c}101.62 \\
(61.10)\end{array}$ & $\begin{array}{c}158.30-48.00 \\
(84.40-51.21)\end{array}$ & $\begin{array}{c}13.85 \\
(11.32)\end{array}$ \\
\hline 26 & $\stackrel{\prime \prime}{(下)}$ & " & $\begin{array}{l}\text { B } \\
\prime \prime\end{array}$ & $\begin{array}{l}18 \\
(1)\end{array}$ & $\begin{array}{l}550.24 \\
432.05)\end{array}$ & $\begin{array}{l}944.80-218.54 \\
(432.05)\end{array}$ & $\begin{array}{c}75.13 \\
(64.00)\end{array}$ & $\begin{array}{l}96.00-44.20 \\
(64.00)\end{array}$ & $\begin{array}{c}13.65 \\
(14.64)\end{array}$ \\
\hline 27 & 现篗間動脉伴行静脉 & 中央部 & $\underset{\prime \prime}{\mathrm{A}}$ & $\begin{array}{c}23 \\
(3)\end{array}$ & $\begin{array}{l}756.05 \\
(885.71)\end{array}$ & $\begin{array}{rr}1,251.68- & 136.82 \\
(1,883.87- & 213.51)\end{array}$ & $\begin{array}{c}81.00 \\
(76.30)\end{array}$ & $\begin{array}{c}189.96-38.40 \\
(92.80-67.20)\end{array}$ & $\begin{array}{c}10.71 \\
(8.61) \\
\end{array}$ \\
\hline 28 & $"$ & " & $\begin{array}{l}\text { B } \\
\prime \prime\end{array}$ & $\begin{array}{c}19 \\
(3)\end{array}$ & $\begin{array}{l}551.31 \\
(560.28) \\
\end{array}$ & $\begin{array}{ll}961.80- & 348.26 \\
783.43- & 364.29)\end{array}$ & $\begin{array}{r}87.10 \\
(72.53) \\
\end{array}$ & $\begin{array}{c}142.48-38.40 \\
(89.60-51.20) \\
\end{array}$ & $\begin{array}{c}15.79 \\
(12.95)\end{array}$ \\
\hline 29 & 浅 掌静 脉 弓 & $"$ & $\underset{\prime \prime}{\mathrm{A}}$ & $\begin{array}{c}23 \\
(2)\end{array}$ & $\begin{array}{l}435.95 \\
500.30)\end{array}$ & 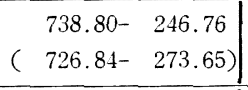 & $\begin{array}{c}87.67 \\
(57.60)\end{array}$ & $\begin{array}{c}158.30-35.20 \\
(67.20-48.00) \\
\end{array}$ & $\begin{array}{c}20.11 \\
(11.51)\end{array}$ \\
\hline 30 & $"$ & $"$ & ${ }^{\text {B }}$ & $\begin{array}{l}17 \\
(2)\end{array}$ & $\begin{array}{l}306.56 \\
(\quad 514.02) \\
\end{array}$ & 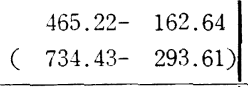 & $\begin{array}{c}61.52 \\
(52.00)\end{array}$ & $\begin{array}{c}126.64-28.80 \\
(57.60-46.40)\end{array}$ & $\begin{array}{c}20.06 \\
(10.11)\end{array}$ \\
\hline 31 & 深 掌 静 脉. 弓 & 中 央部 & $\underset{\prime \prime}{\mathrm{A}}$ & $\begin{array}{c}21 \\
(3)\end{array}$ & $\begin{array}{l}455.56 \\
(\quad 405.71) \\
\end{array}$ & $\left(\begin{array}{ll}717.34- & 192.98 \\
(604.67- & 252.50)\end{array}\right.$ & $\begin{array}{c}123.39 \\
(107.00)\end{array}$ & $\begin{array}{c}189.96-64.00 \\
(205.79-35.20)\end{array}$ & $\begin{array}{l}27.08 \\
(26.31)\end{array}$ \\
\hline 32 & " & " & ${ }_{\prime \prime}^{\mathrm{B}}$ & $\begin{array}{c}13 \\
(1)\end{array}$ & $\begin{array}{l}318.14 \\
(548.61) \\
\end{array}$ & $\begin{array}{ll}498.09- & 168.17 \\
(\quad 548.61) & \\
\end{array}$ & $\begin{array}{c}112.80 \\
(158.30)\end{array}$ & $\begin{array}{l}144.00-51.20 \\
(158.30)\end{array}$ & $\begin{array}{l}35.45 \\
(28.81)\end{array}$ \\
\hline 33 & 緿 掌 指 静 脉 & $\begin{array}{l}(\text { II } \sim \text { III }) \\
\text { 中 央 部; }\end{array}$ & A & $\begin{array}{c}16 \\
(3)\end{array}$ & $\begin{array}{l}268.64 \\
(\quad 275.39) \\
\end{array}$ & $\begin{array}{rr}766.29- & 100.77 \\
(\quad 494.06- & 63.32)\end{array}$ & $\begin{array}{r}64.98 \\
(57.60) \\
\end{array}$ & $\begin{array}{c}96.00-38.23 \\
(96.00-25.60) \\
\end{array}$ & $\begin{array}{r}24.19 \\
(20.92) \\
\end{array}$ \\
\hline 34 & " & " & ${ }_{\prime \prime}^{\mathrm{B}}$ & $\begin{array}{l}15 \\
(2)\end{array}$ & $\begin{array}{l}157.84 \\
(177.76)\end{array}$ & 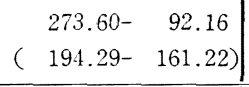 & $\begin{array}{c}46.82 \\
(51.20)\end{array}$ & $\begin{array}{c}84.80-25.60 \\
(86.40-16.00)\end{array}$ & $\begin{array}{l}29.03 \\
(28.80)\end{array}$ \\
\hline 35 & 固有堂側指静脉 & $\begin{array}{l}\text { (西)第一 } \\
\text { 節㧼測中 } \\
\text { 央 }\end{array}$ & $\begin{array}{l}\text { A } \\
" 1\end{array}$ & $\begin{array}{c}17 \\
(2)\end{array}$ & $\begin{array}{l}204.30 \\
(\quad 213.19) \\
\end{array}$ & $\left(\begin{array}{rr}509.89- & 61.91 \\
(252.09- & 174.28\end{array}\right)$ & $\begin{array}{c}44.79 \\
(49.60)\end{array}$ & $\begin{array}{c}110.81-19.20 \\
(63.40-35.80)\end{array}$ & $\begin{array}{c}21.93 \\
(23.26)\end{array}$ \\
\hline 36 & " & $"$ & $\begin{array}{l}\text { B } \\
\prime \prime\end{array}$ & $\begin{array}{c}17 \\
(1)\end{array}$ & $\begin{array}{l}183.31 \\
(158.86)\end{array}$ & $\begin{array}{r}721.32- \\
(158.86)\end{array}$ & $\begin{array}{c}41.39 \\
(19.20)\end{array}$ & $\begin{array}{l}84.20-25.60 \\
(19.20)\end{array}$ & $\begin{array}{c}22.57 \\
(12.06)\end{array}$ \\
\hline
\end{tabular}

表 3. 上肢静脉管の人生期別内径の平均值 (ठ)

\begin{tabular}{|c|c|c|c|c|c|c|c|c|c|c|c|c|c|c|c|}
\hline \multirow{2}{*}{ o. } & 住 & \multicolumn{2}{|c|}{ 青 年 期 } & \multicolumn{2}{|c|}{ 第一成熟期 } & \multicolumn{2}{|c|}{ 第二成熟期 } & \multicolumn{2}{|c|}{ 第三成熟期 } & \multicolumn{2}{|c|}{ 第四成熟期 } & \multicolumn{2}{|c|}{ 第一老年期 } & \multicolumn{2}{|c|}{ 第二老年期 } \\
\hline & & $\mathrm{N}$ & M & $\mathrm{N}$ & M & $\mathrm{N}$ & M & $\mathrm{N}$ & M & $\mathrm{N}$ & M & $\mathrm{N}$ & M & $\mathrm{N}$ & M \\
\hline 1 & 撓側皮静脉（I） & 1 & & 9 & 1,615 & 5 & & 4 & $1,852.73$ & & $1,681.08$ & 4 & .21 & 4 &, 586.63 \\
\hline 2 & (III) & 1 & & 9 & & 4 & & & & 4 & & 4 & & 4 & \\
\hline 3 & (IV) & 1 & 3.01 & 9 & $1,615.19$ & 4 & 04 & 4 & $1,541.21$ & 4 & $1,993.51$ & 4 & $1,749.46$ & 4 & 4.54 \\
\hline 4 & (VI) & 1 & .91 & 9 & & 4 & & 5 & .01 & 3 & 92 & 4 & 57.49 & 4 & .47 \\
\hline 5 & 尺側皮静脉 (I) & 1 & 2.162 .76 & 9 & $1,901.85$ & 5 & $2,471.04$ & 5 & $1.997,79$ & 3 & $2,309.50$ & 4 & $2,432.68$ & 3 & $2,528.50$ \\
\hline 6 & " $\quad$ (II) & 1 & $1,653.08$ & 9 & $1,807.56$ & 5 & $2,657.82$ & 5 & $2,263.48$ & 4 & $3,594.08$ & 4 & $2,023.40$ & 3 & $2,775.31$ \\
\hline 7 & (III) & 1 & 806.62 & 6 & & 3 & $1,940.35$ & 5 & & 2 & & 2 &, 25 & 4 & \\
\hline 8 & $(\mathrm{~V})$ & 1 & $1,216.49$ & 5 & $1,445.51$ & 4 & 941.30 & 4 & $1,999.57$ & 2 & $1,347.42$ & 4 & $1,024.72$ & 4 & $1,882.01$ \\
\hline 9 & 肘正中皮静脉 & 1 & 1.050 .73 & 9 & $1,645.42$ & 5 & $2,054.92$ & 5 & $1,919.74$ & 4 & $1,749.29$ & 4 & $1,323.75$ & 4 & $2,223.87$ \\
\hline 10 & 前腕正中皮静脉 & 1 & $1,068.89$ & 9 & 949.00 & 4 & $1,425.75$ & 4 & $1,405.41$ & 2 & 837,44 & 4 & 797.29 & 4 & 1.032 .74 \\
\hline 11 & 背側中手静脉 & 1 & 916.08 & 6 & $1,088.52$ & 4 & & 3 & & 4 & & 4 & & 2 & $1,098.42$ \\
\hline 12 & 固有背側指静脉 & 1 & 483.98 & 6 & 620.27 & 4 & 681.54 & 3 & 660.29 & 2 & 767.73 & 2 & 866.21 & 2 & 890.89 \\
\hline 13 & 上腕動脉伴行青准脉 (上) & 1 & $4,918.89$ & 81 & $4,617.91$ & 5 & $4,531.75$ & 5 & $3,472.67$ & 3 & $3,334.83$ & 4 & $6,054.83$ & 2 & $4,206.74$ \\
\hline
\end{tabular}




$$
\text { (1585) }-143-
$$

\begin{tabular}{|c|c|c|c|c|c|c|c|c|c|c|c|c|c|c|c|c|c|}
\hline 14 & & $"$ & （上） & 1 & $2,130.13$ & 6 & $2,289.32$ & 4 & $2,693.82$ & 1 & $2,082.57$ & 1 & $2,329.47$ & 2 & $2,611.63$ & 1 & $2,941.36$ \\
\hline 5 & & $n$ & (下) & 1 & $2,271.68$ & 8 & $2,557.10$ & 5 & $2,707.21$ & 5 & $2,459,27$ & 4 & $1,875.36$ & 4 & $2,140.58$ & 2 & $2,288.35$ \\
\hline 6 & & $"$ & (下) & 1 & $1,815.31$ & 6 & $2,324.69$ & 4 & $2,283.03$ & 2 & $2,460.76$ & 1 & $2,070.84$ & 2 & $1,933.23$ & & $2,188.74$ \\
\hline 17 & 上腕深動 & 加脉 伴 & 行静脉 & 1 & $1,089.54$ & 6 & $2,542.90$ & 4 & $2,036.05$ & 4 & $2,557.75$ & 3 & $2,723.67$ & 2 & $2,390.36$ & 2 & $2,365.20$ \\
\hline 18 & & $" \prime$ & & 1 & $1,068.94$ & 4 & $2,204 \cdot 84$ & 4 & $1,963.04$ & 2 & $1,913.06$ & 2 & $2,394.32$ & 1 & 2.111 .28 & 1 & $2,086.60$ \\
\hline 19 & 橈盈動脉 & 永伴行青 & 静脉（上） & 1 & 693.03 & 7 & 915.27 & 3 & $1,301.55$ & 5 & $1,513.21$ & 3 & 871.45 & 4 & $1,174.49$ & 4 & $1,347.84$ \\
\hline 20 & & $"$ & （上） & 1 & 677.28 & 5 & 969.46 & 2 & $1,199.63$ & 3 & 956.78 & 2 & 761.89 & 2 & 772.00 & & 856.26 \\
\hline 21 & & " & (下) & 1 & 518.54 & 7 & 820.94 & 3 & 603.66 & 5 & 638.44 & 3 & $1,188.89$ & 4 & 674.62 & 4 & $1,009.02$ \\
\hline 22 & & $"$ & (下) & 1 & 501.83 & 6 & 717.59 & 3 & $1,061.37$ & 3 & 605.60 & 3 & $1,392.84$ & 2 & 735.19 & & 804.41 \\
\hline 23 & 尺帠動胁 & 水伴行青 & 筆脉（上） & 1 & $1,552.65$ & 7 & $1,616.20$ & 3 & $2,026.98$ & 5 & $1,961.63$ & 3 & $1,526.07$ & 4 & $1,314.67$ & & $1,806,34$ \\
\hline 24 & & $"$ & (上) & 1 & 770.49 & 5 & 864.62 & 2 & 893.93 & 3 & 640.29 & 2 & 570.19 & 2 & 998.50 & & 806.67 \\
\hline 25 & & $n$ & (下) & 1 & 654.65 & 7 & 830.21 & 4 & 638.61 & 5 & 731.18 & 3 & 762.01 & 4 & 676.77 & & 713.72 \\
\hline 26 & & $"$ & (下) & 1 & 537.90 & 5 & 587.91 & 2 & 544.69 & 3 & 467.37 & 2 & 537.21 & 2 & 593.32 & & 558.47 \\
\hline 27 & 総骨間動 & 氻脉 伴 & 行静脉 & 1 & 501,01 & 6 & 779.86 & 3 & 795.46 & 4 & 728.33 & 3 & 833.91 & 4 & 716.76 & & 770,20 \\
\hline 28 & & $"$ & & 1 & 398.88 & 4 & 653.94 & 4 & 545.47 & 4 & 500.58 & 2 & 551.31 & 2 & 541.02 & & 545.76 \\
\hline 29 & 线 & 静 & & 1 & 352.80 & 6 & 439.93 & 3 & 446.59 & 4 & 482.73 & 3 & 370.00 & 4 & 391.39 & & 544.10 \\
\hline 30 & & $"$ & & 1 & 183.05 & 4 & 333.19 & 3 & 210.61 & 3 & 318.28 & 2 & 307.39 & 2 & 328.80 & 2 & 345.98 \\
\hline 31 & 深 & 静 & 脉 & 1 & 512.34 & 6 & 455.42 & 3 & 491.95 & 4 & 381.07 & 2 & 399.89 & 3 & 506.67 & & 500.96 \\
\hline 32 & & " & & 1 & 300.87 & 4 & 280.65 & 2 & 295.30 & 2 & 311.79 & 1 & 305.80 & 2 & 408.11 & 1 & 376.15 \\
\hline 33 & 総 & 指 & 脉 & 1 & 200.57 & 4 & 278.24 & 2 & 382.35 & 3 & 189.57 & 2 & 325.89 & 2 & 237.28 & 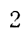 & 262.47 \\
\hline 34 & & $"$ & & 1 & 134.73 & 4 & 211.79 & 2 & 107.00 & 2 & 163.40 & 2 & 125.00 & 2 & 133.62 & 2 & 163.84 \\
\hline 35 & 固有掌 & 側 f & 旨静脉 & 1 & 81.91 & 4 & 235.40 & 2 & 360.60 & 3 & 204.49 & 3 & 176.32 & 2 & 198.63 & 2 & 192.76 \\
\hline 36 & & $"$ & & 1 & 73.72 & 4 & 197.91 & 2 & 237.16 & 3 & 184.04 & 3 & 168.68 & 2 & 186.44 & 2 & 173.48 \\
\hline
\end{tabular}

れる。

\section{B. 上肢静脉管の壁厚の計測}

\section{1. 壁厚の平均值}

各上肢静脉に招いて 4 5 個所の壁厚を計測し, 去 の平均值をもつて壁厚侹とした。

之の全人生期平均值並に最大, 最小值を表 2 に揭げ る。先人の動脉に括ける報告によれば概して直径に準 じ, 静脉に和ける報告によれば, 暁侧皮静脉は上肢上 端に括いて最も薄く, 周囲径の増大に逆行し, 他はす ベて平行すると述べている。著者の数值も之とほが同
榚なる8，橈例皮静脉のみならすき侧皮静脉に拓いて も逆行している。

\section{2. 年令と壁厚との関係}

先人の報告に上れば, 動脉管の場合加令と共に増加 の傾向にあり, 静脉管の場合, 皮静脉に出いては確然 たる年令的関係は認められず, 深静脉に扣いて僅かに その傾向ありと。表 4 に示す如く皮静脉の結果はほよ゙ 同栏なるも，深静脉に扔いては第四成熟期または第一 老年期までは漸增し，第二老年期になると減少する傾 向が見られた。

表 4. 上肢静脉管の人生期別壁厚平均值 (ふ)

\begin{tabular}{|c|c|c|c|c|c|c|c|c|c|c|c|c|c|c|c|}
\hline \multirow{2}{*}{ No. } & \multirow{2}{*}{ 静 脉 名 } & \multicolumn{2}{|c|}{ 青 年 期 } & \multicolumn{2}{|c|}{ 第一成熟期 } & \multicolumn{2}{|c|}{ 第二成熟期 } & \multicolumn{2}{|c|}{ 第三成熟期 } & \multicolumn{2}{|c|}{ 第四成熟期 } & \multicolumn{2}{|c|}{ 第一老年期 } & \multicolumn{2}{|c|}{ 第二老年期 } \\
\hline & & $\mathrm{N}$ & M & $N$ & $\mathrm{M}$ & $\mathrm{N}$ & M & $\mathrm{N}$ & M & $\mathrm{N}$ & M & $\mathrm{N}$ & M & $\mathrm{N}$ & M \\
\hline 1 & 橈 側 皮静脉 (I) & 1 & 177.60 & 9 & 200.11 & 5 & 141.53 & 4 & 154.45 & 7 & 162.47 & & 142.50 & 4 & 132.78 \\
\hline 2 & $" \quad$ (III) & 1 & 234.94 & 9 & 277.37 & 4 & 217.66 & 4 & 232.76 & 4 & 238.51 & & 237.59 & 4 & 240.03 \\
\hline 3 & (IV) & 1 & 254.25 & 9 & & 4 & 281.39 & 4 & 288 & 4 & 261.72 & 4 & 247.61 & 4 & 290.50 \\
\hline 4 & (VI) & 1 & 264.09 & 9 & 277.47 & 4 & 253.28 & 5 & 332.16 & 4 & 259.85 & 4 & 247.94 & 4 & 289.49 \\
\hline 5 & 尺側皮静続 (I) & 1 & 236.70 & 9 & & 5 & & 5 & & 3 & & 4 & & 3 & \\
\hline 6 & $" \quad$ (II) & 1 & 253.24 & 9 & 225.89 & 5 & 256.13 & 5 & 284.42 & 4 & 234.86 & 4 & 310.37 & 3 & 188.28 \\
\hline 7 & (III) & 1 & 239.60 & 6 & 284.98 & 3 & 311.56 & 5 & 228.32 & 2 & 294.55 & 2 & & 4 & 250.98 \\
\hline 8 & $(\mathrm{~V})$ & 1 & 226.60 & 5 & 241.62 & 4 & 226.49 & 4 & 191.70 & 2 & 207.65 & 4 & & 4 & 251.39 \\
\hline 9 & 肘正中皮静脉 & 1 & 189.96 & 9 & 233.06 & 5 & 286.13 & 5 & 231.42 & 4 & 209.03 & 4 & 236.21 & 4 & 215.60 \\
\hline 10 & 前腕 正中皮静脉 & 1 & 250.60 & 9 & & 4 & 228.19 & 4 & 216.76 & 2 & 209.27 & 4 & 198.50 & 4 & 216.01 \\
\hline 11 & 背 側 中手静脉 & 1 & 171.89 & 6 & & 4 & 174.13 & 3 & 269.78 & 4 & 199.48 & 4 & 207.89 & 2 & 230.59 \\
\hline 12 & 固有背側指静脉 & 1 & & 6 & & 4 & 149.61 & 3 & 188.19 & 2 & 203.70 & 2 & 216.61 & 2 & 176.53 \\
\hline 13 & 上腕動脉伴行静脉 (上) & 1 & 179.15 & 8 & 229.16 & 5 & 170.96 & 5 & 155.13 & 3 & 211.59 & 4 & 219.42 & 2 & 227.38 \\
\hline 14 & $"$ (上) & 1 & 161.23 & 6 & 206.24 & 4 & 153.86 & 1 & 139.62 & 1 & 199.43 & 2 & 197.48 & 1 & 204.64 \\
\hline
\end{tabular}




\begin{tabular}{|c|c|c|c|c|c|c|c|c|c|c|c|c|c|c|c|c|c|}
\hline 15 & & " & (下) & 1 & 137.60 & 8 & 173.14 & 5 & 145.64 & 5 & 163.56 & 4 & 175.96 & 4 & 170.54 & 2 & 175.96 \\
\hline 6 & & " & (下) & 1 & 124.98 & 5 & 132.84 & 4 & 115.18 & 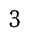 & 192.12 & 1 & 208.99 & 2 & 145.50 & 1 & 190.77 \\
\hline & 上腕深動 & 脉 伴 & 行静脉 & 1 & 101.62 & 6 & 153.74 & 4 & 83.38 & 4 & 81.81 & 3 & 112.16 & 2 & 120.76 & 2 & 122.61 \\
\hline & & $"$ & & 1 & 64.32 & 4 & 93.74 & & 65.04 & 2 & 55.93 & 2 & 62.08 & 1 & 127.40 & 1 & 90.00 \\
\hline 19 & 橈胃篹脉 & 伴行青 & 解脉 (上) & 1 & 114.13 & 7 & 128.14 & 3 & 120.27 & 5 & 148.58 & 3 & 159.97 & 4 & 168.91 & 4 & 141.29 \\
\hline & & $"$ & (上) & 1 & 102.13 & 5 & 102.69 & ? & 88.64 & 3 & 124.30 & 2 & 88.20 & 2 & 127.15 & 2 & 90.04 \\
\hline & & " & (下) & 1 & 96.00 & 7 & 91.93 & 3 & 137.68 & 5 & 129.39 & 3 & 84.82 & 4 & 125.67 & 4 & 98.13 \\
\hline 22 & & $"$ & (下) & 1 & 76.00 & 6 & 85.60 & 3 & 84.82 & 3 & 109.42 & 3 & 83.70 & 2 & 122.68 & 1 & 82.00 \\
\hline 23 & 尺骨動脉 & 伴行青 & 净脉（上） & 1 & 123.45 & 7 & 119.06 & 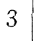 & 158.08 & 5 & 107.26 & 3 & 169.14 & 4 & 193.65 & 4 & 130.46 \\
\hline & & $"$ & （上） & 1 & 98.58 & 5 & 97.38 & 2 & 112.84 & 3 & 116.82 & 2 & 131.20 & 2 & 150.81 & 2 & 117.09 \\
\hline 25 & & $"$ & (下) & 1 & 101.30 & 7 & 103.25 & 4 & 116.08 & 5 & 94.21 & 3 & 93.27 & 4 & 102.52 & 3 & 94.67 \\
\hline 26 & & $"$ & (下) & 1 & 62.79 & $\tilde{\jmath}$ & 77.44 & 2 & 82.30 & 3 & 68.27 & 2 & 66.78 & 2 & 88.00 & 3 & 73.80 \\
\hline 27 & 総骨間動 & 脉伴 & 行静脉 & 1 & 90.90 & 6 & 75.27 & 3 & 79.40 & 4 & 100.21 & 3 & 69.33 & 4 & 85.30 & 2 & 66.10 \\
\hline 28 & & $"$ & & 1 & 72.47 & 4 & 91.50 & 4 & 81.85 & 4 & 94.75 & 2 & 85.93 & 2 & 88.40 & 2 & 88.27 \\
\hline 29 & 倠 & 静 & 脉 & 1 & 67.20 & 6 & 87.32 & 3 & 73.85 & 4 & 97.18 & 3 & 75.82 & 4 & 100.25 & 2 & 75.84 \\
\hline 30 & & $"$ & & 1 & 49.18 & 4 & 74.42 & 3 & 64.48 & 3 & 46.93 & 2 & 53.16 & 2 & 67.08 & 2 & 62.14 \\
\hline 31 & 深 掌 & 静 & 脉 & 1 & 108.00 & 6 & 116.53 & 3 & 110.49 & 4 & 145.19 & 2 & 117.10 & 2 & 132.70 & 2 & 123.40 \\
\hline 32 & & $"$ & & 1 & 89.60 & 4 & 103.00 & 2 & 106.13 & 2 & 128.40 & 1 & 114.03 & 2 & 126.40 & 2 & 120.36 \\
\hline 33 & 彩 掌 & 指 & 静 & 1 & 57.60 & 4 & 66.60 & 2 & 68.46 & 3 & 58.67 & 2 & 56.49 & 2 & 78.69 & 2 & 66.18 \\
\hline 31 & & $"$ & & 1 & 36.50 & 4 & 47.41 & 2 & 42.61 & 2 & 39.28 & 2 & 44.21 & 2 & 65.81 & 2 & 47.23 \\
\hline 35 & 固有党 & 側 f & 旨青静脉 & 1 & 19.20 & 4 & 30.00 & 2 & $79.4 \mathrm{I}$ & 3 & 53.33 & 3 & 40.33 & 2 & 54.40 & 2 & 36.80 \\
\hline 36 & & $"$ & & 1 & 16.00 & 4 & 25.60 & 2 & 67.99 & 3 & 51.20 & 3 & 41.60 & 2 & 54.40 & 2 & 32.00 \\
\hline
\end{tabular}

\section{C. 上肢静脉管の厚度率}

\section{1. 厚度率の平均值}

一部位における内径に对する厚度を知るために壁厚

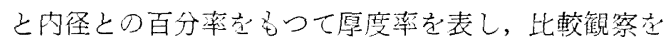
行つた。表 2 に示す如く, 皮静脉深静脉を通じ, 未梢 方に扰いて厚度率大にして，中心方に行くにしたがい 厚度率小となる。之は件静脉を通じよく先人の報告と
一致する。

\section{2. 年令と厚度率との関係}

各人生期別の厚度率を表 5 亿揭げる。

動脉管に扣けるが如き逐年命的增加怯見られず，第 一老年期までは確然たる倾向はないが，第二老年期以 後は幾分小よなるように思われる。

表 5. 上肢静脉管の人生期別厚度率の平均值 (仓)

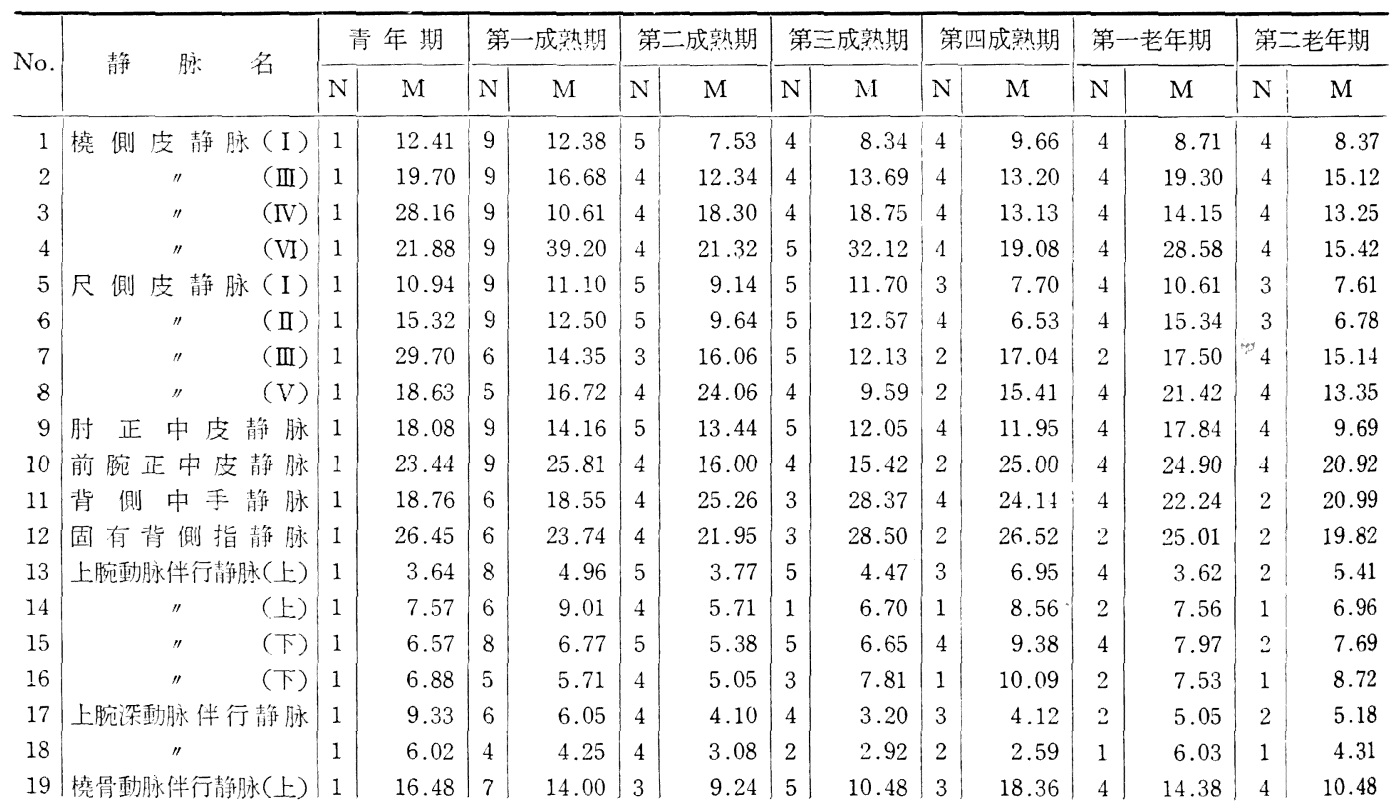




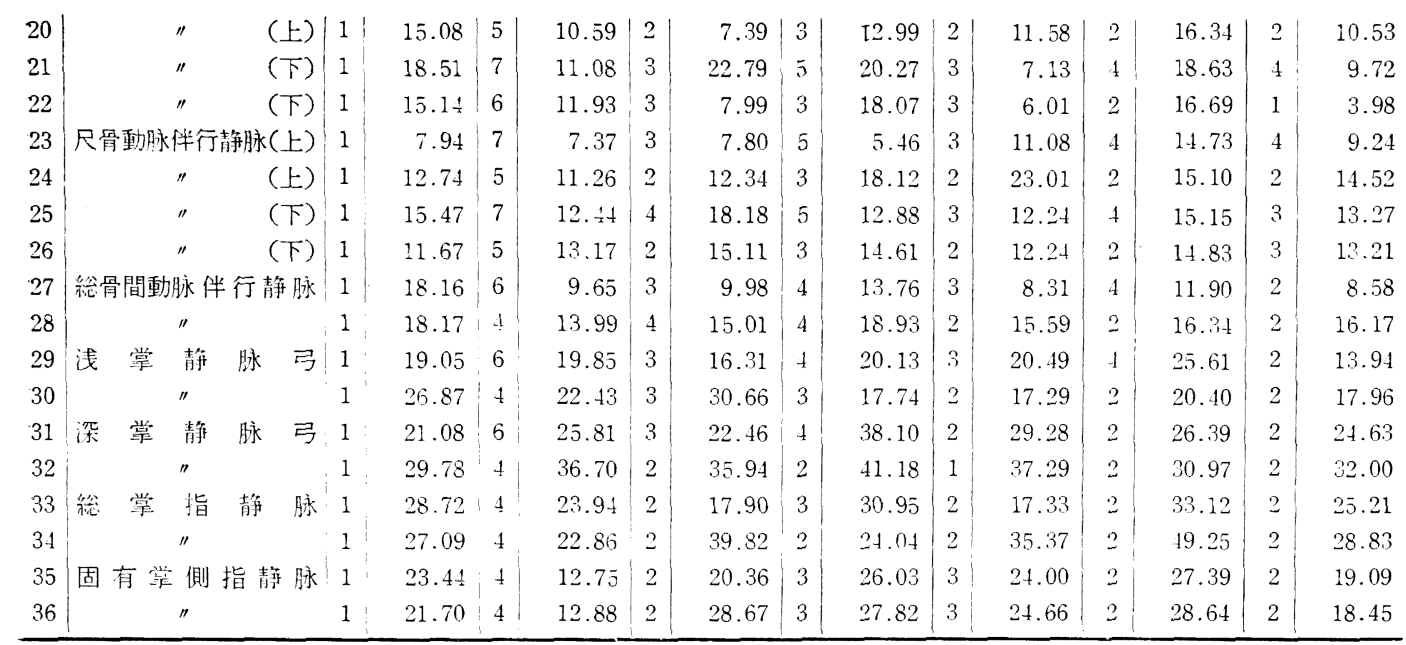

\section{D．上肢静脉管の年令別左右比較}

今井の報告に上れば, 動脉管の直径は上腕, 前腕之 もに右〉左であり, 手指になると左>右の場合も可成 り現われると述べている。山下によれば, 静脉管周 径及び壁厚恃皮下深部共一定の意義ある側別差を認め ざるも，個体別には㐫る程度の相違が热められると報
告している、著者は20例について左右各部の比較計 測を行つた結果, 部位別・個体別飞は側別差を認めた が，全体的には有意性の側別差は認められない。たよ゙

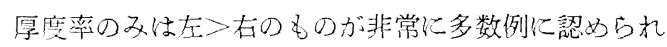
た：実側值の一部を拔粋して表 6 亿揭任る。

表 6. 上肢静脉管の年分別左右比較投粋卡段左

\begin{tabular}{|c|c|c|c|c|c|c|c|c|c|}
\hline 部酯 & 年令 怕 & 生別 & 内 径 & & & \multicolumn{2}{|c|}{ 中膜及び筋線維数 } & \multirow{2}{*}{$\frac{\text { 外 膜 }}{70.40}$} & \multirow{2}{*}{$\frac{\text { 厚度滦 }}{6.18}$} \\
\hline \multirow[b]{2}{*}{ 毫 } & \multirow{2}{*}{$28 才$} & \multirow{2}{*}{$\delta$} & $2,048.89$ & 126.64 & 4.80 & 57.60 & $8 \sim 9$ & & \\
\hline & & & $1,664.97$ & 187.60 & 11.60 & 64.00 & $7 \sim 8$ & 112.00 & 11.69 \\
\hline \multirow{2}{*}{$\begin{array}{l}\text { 側 } \\
\text { 皮 }\end{array}$} & \multirow{2}{*}{$40 才$} & \multirow{2}{*}{$\hat{\delta}$} & $2,164.32$ & 164.80 & 4.80 & 60.80 & $8 \sim 9$ & 99.20 & 8.61 \\
\hline & & & 1.552 .24 & 188.79 & 6.40 & 70.40 & $9 \sim 10$ & 112.00 & 12.16 \\
\hline \multirow{8}{*}{ 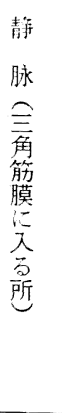 } & \multirow{2}{*}{$50 才$} & \multirow{2}{*}{$\hat{\delta}$} & $1,911.91$ & 78.60 & 4.80 & 19.20 & $6 \sim 7$ & 54.4 & 4.11 \\
\hline & & & $1,803.70$ & 189.96 & 8.00 & 80.00 & 9 & 96.00 & 10.47 \\
\hline & \multirow{2}{*}{60 才 } & \multirow{2}{*}{$\hat{\delta}$} & 832.54 & 179.20 & 3.20 & 48.00 & 9 & 128.00 & 21.52 \\
\hline & & & 550.30 & 158.30 & 9.60 & 55.40 & $6 \sim 7$ & 112.00 & 26.47 \\
\hline & \multirow{2}{*}{71 才 } & \multirow{2}{*}{$\hat{\delta}$} & $2,465.47$ & 236.28 & 3.20 & 57.60 & 9 & 76.00 & 9.54 \\
\hline & & & $1,846.56$ & 76.80 & 3.20 & 32.00 & 8 & 44.80 & 4.16 \\
\hline & \multirow{2}{*}{76 才 } & \multirow{2}{*}{ q } & $2,818.58$ & 126.64 & 4.80 & 38.40 & 8 & 112.00 & 4.49 \\
\hline & & & $2,226.10$ & 118.40 & 3.20 & 51.20 & 6 & 64.00 & 5.09 \\
\hline \multirow{6}{*}{$\begin{array}{l}\text { 上 } \\
\text { 腕 } \\
\text { 動 } \\
\text { 脉 } \\
\text { 伴 } \\
\text { 行 }\end{array}$} & \multirow{2}{*}{$28 才$} & \multirow{2}{*}{$\begin{array}{cc} & \bar{A} \\
\hat{\delta} & \mathrm{B} \\
\mathrm{A} \\
\mathrm{B}\end{array}$} & $\begin{array}{l}2,410.80 \\
1.355 .23\end{array}$ & $\begin{array}{r}73.30 \\
126.64 \\
\end{array}$ & $\begin{array}{r}3.20 \\
3.20 \\
\end{array}$ & $\begin{array}{l}28.80 \\
44.40\end{array}$ & $\begin{array}{c}5 \\
4 \sim 5 \\
\end{array}$ & $\begin{array}{l}38.40 \\
63.32 \\
\end{array}$ & $\begin{array}{l}3.04 \\
9.37 \\
\end{array}$ \\
\hline & & & $\begin{array}{l}2,905.87 \\
2,377.53 \\
\end{array}$ & $\begin{array}{r}110.81 \\
94.98 \\
\end{array}$ & $\begin{array}{l}3.20 \\
3.20\end{array}$ & $\begin{array}{r}32.00 \\
31.00 \\
\end{array}$ & $\begin{array}{l}8 \\
7 \\
\end{array}$ & $\begin{array}{l}63.32 \\
63.32 \\
\end{array}$ & $\begin{array}{l}3.81 \\
3.99 \\
\end{array}$ \\
\hline & \multirow{2}{*}{$30 才$} & \multirow{2}{*}{$\begin{array}{ll} & \mathrm{A} \\
& \mathrm{A}\end{array}$} & $3,283.97$ & 174.11 & 7.90 & 71.23 & 6 & 94.98 & 5.30 \\
\hline & & & $4,188.41$ & 174.13 & 15.83 & 47.49 & 10 & 110.81 & 4.16 \\
\hline & & $\begin{array}{l}\mathrm{A} \\
\mathrm{B}\end{array}$ & $\begin{array}{l}3,468.89 \\
2,295.17\end{array}$ & $\begin{array}{l}64.00 \\
79.15\end{array}$ & $\begin{array}{l}3.20 \\
3.20 \\
\end{array}$ & $\begin{array}{l}28.80 \\
31.66\end{array}$ & $\stackrel{7}{6} 7$ & $\begin{array}{l}35.20 \\
39.20 \\
\end{array}$ & $\begin{array}{l}1.85 \\
3.45\end{array}$ \\
\hline & $40 才$ & $\begin{array}{cc}\hat{\sigma} & 0 \\
& \mathrm{~A} \\
\mathrm{~B}\end{array} \mid$ & $\begin{array}{r}3,587.68 \\
763.27\end{array}$ & $\begin{array}{r}94.98 \\
110.81\end{array}$ & $\begin{array}{l}3.20 \\
7.90\end{array}$ & $\begin{array}{l}35.20 \\
47.49\end{array}$ & $\begin{array}{r}8 \\
10\end{array}$ & $\begin{array}{l}51.20 \\
55.10\end{array}$ & $\begin{array}{r}2.65 \\
14.52\end{array}$ \\
\hline
\end{tabular}




\begin{tabular}{|c|c|c|c|c|c|c|c|c|}
\hline \multirow{2}{*}{50 才 } & \multirow{2}{*}{${ }^{8} \begin{array}{l}\mathrm{A} \\
\mathrm{A}\end{array}$} & $3,787.10$ & 205.79 & 8.00 & 79.15 & 10 & 96.00 & 5.43 \\
\hline & & $1,273.98$ & 183.15 & 3.20 & 70.40 & $7 \sim 8$ & 112.00 & 14.38 \\
\hline \multirow{2}{*}{60 才 } & \multirow{2}{*}{$\hat{\mathrm{o}} \mathrm{B}$} & $\begin{array}{r}4,505.96 \\
1,692.36 \\
\end{array}$ & $\begin{array}{r}143.00 \\
44.80 \\
\end{array}$ & $\begin{array}{l}3.20 \\
3.20 \\
\end{array}$ & $\begin{array}{l}55.40 \\
19.20 \\
\end{array}$ & $\begin{array}{c}10 \\
7 \sim 8\end{array}$ & $\begin{array}{l}84.40 \\
22.40 \\
\end{array}$ & $\begin{array}{l}3.64 \\
2.06 \\
\end{array}$ \\
\hline & & $5,958.94$ & 174.13 & 7.90 & 79.15 & 8 & 87.06 & 2.92 \\
\hline \multirow{2}{*}{76 才 } & \multirow[b]{2}{*}{${ }^{\circ} \mathrm{A}$} & $3,974.52$ & 80.00 & 3.20 & 22.40 & 7 & 54.40 & 2.01 \\
\hline & & $\begin{array}{l}2,713.48 \\
3,471.01 \\
\end{array}$ & $\begin{array}{l}112.00 \\
105.20 \\
\end{array}$ & $\begin{array}{r}3.20 \\
3.20 \\
\end{array}$ & $\begin{array}{l}44.80 \\
32.00 \\
\end{array}$ & $\begin{array}{l}6 \\
6 \\
\end{array}$ & $\begin{array}{l}64.00 \\
70.40 \\
\end{array}$ & $\begin{array}{r}4.13 \\
3.04 \\
\end{array}$ \\
\hline
\end{tabular}

\section{E. 暁尺両伴行静脉の形態的比較}

静脉管は各々細枝を合流してその太さを増加する が，一見同様に考党られる橈・尺雨伴行静脉の動脉管 に伴行する枝の数の異る交認め，分類して報告する。
表 7 に示す如 ‘， 尺側の方が暁側に比べ，性別・側 別及び年令の別なくはるかに伴行する枝数が多くその 理由は不明なるも興味古ることと思われる。

表 7. 櫵, 尺両伴行静脉の形態的比較

\begin{tabular}{|c|c|c|c|c|c|c|c|c|}
\hline 部 位 & 本 数 & 2 本のもの & & 及本のもの & & 4 本の屯の & & 計 \\
\hline 橈骨動脉伴行静脉 & (中央 部) & 31 & & 3 & & 0 & & 34 \\
\hline 尺骨動脉伴行静脉 & (中 央 部) & 16 & & 8 & & 3 & & 27 \\
\hline 位 & 本 & 年 & 令 & 性 & 別 & & 左 右 & 右 別 \\
\hline \multirow{2}{*}{$\begin{array}{c}\text { 橈骨動脉伴行静脉 } \\
\text { (中央部) }\end{array}$} & 2 本のもの & \multicolumn{2}{|l|}{ 省＼cjkstart略 } & & & & & \\
\hline & $3+\infty$ もの & 26 才。左, & 30 才 & 今左, & $40 才$ & 今左 & & \\
\hline \multirow{3}{*}{$\begin{array}{c}\text { 尺冎動脉伴行静脉 } \\
\text { (中央部) }\end{array}$} & 2 本 $の$ $\theta$ & 省 略 & & & & & & \\
\hline & 3 本のもの & 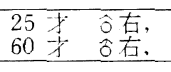 & $\begin{array}{l}27 \text { 求 } \\
61 \text { 列 }\end{array}$ & $\begin{array}{l}\text { ह右, } \\
\text { 否, }\end{array}$ & 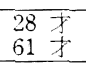 & $\begin{array}{l}\text { 令右, } \\
\text { 左, }\end{array}$ & $\begin{array}{l}49 才 \\
62 才 \\
\end{array}$ & $\begin{array}{l}\text { 余右, } \\
\text { 否, }\end{array}$ \\
\hline & 4 本のむの & 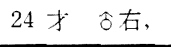 & $28 才$ & s左, & $30 才$ & ○右, & & \\
\hline
\end{tabular}

F. 上肢静脉管内・中・外膜壁厚の計測

静脉は動脉同様 3 層上りなるも, 一般に動脉に比し， 壁は薄く, 筋の発育も劣り, 内膜は不規則な形状を呈 する場合が少なくなく， 3 凰の境界も動脉ほど明瞭で ない。けえに計測にあたり，波状部分は最高，最低部 の中間老基点として翰走筋の内縁まで在内膜とし， こ れより輪走筋の外縁までを中膜とし, それ以後を外膜 として数個所を計測し，穴の平均值をもつてその静脉 管各層の值とした。

\section{1.内膜, 中膜および外膜の平均值}

静脉管内・中・外膜計測の多数例に上る報告なきため
比較し得ざるも，上肢勤脉に関する先人の報告によれ ば,内膜は加令に伴い著しく肥厚し，しかも未梢部ほど その傾向が強いために中心方は外膜〉内膜となり，末 㑕方は逆に内膜>外膜こなる。中膜はその両者の和よ りはるかに大でするが，静脉管に扣いては表 8 に示寸 如く, 全く之と異なり各値己も著明な変化は認められ ず,たぶ各層(特に皮下静脉内膜)に扣いて时,腕関節部 附近に值の增大を見る。な扮中膜と外膜の比を見るに，

皮静脉に㧅、ては, 中心方約 $1: 2$, 未梢方 $2: 3$ 深静脉に招いては，中心方約 $1: 2$, 未梢方 $1: 1$ となり，明らかな差を示している。

表8. 上肢静脉管の内. 中. 外膜壁厚の平均值卡段( ) 点

\begin{tabular}{|c|c|c|c|c|c|c|c|c|c|c|}
\hline \multirow{2}{*}{ No. } & \multirow{2}{*}{ 摮 } & \multirow{2}{*}{ 架 } & \multirow{2}{*}{ 名 } & \multirow{2}{*}{ N } & \multicolumn{2}{|l|}{ 内 } & \multicolumn{2}{|l|}{ 中 } & \multicolumn{2}{|l|}{ 外 } \\
\hline & & & & & M & 最大値〜最小值 & M & 最大值～最小值 & M & 最大值～最小值 \\
\hline \multirow{2}{*}{1} & \multirow{2}{*}{ 橈 側 } & \multirow{2}{*}{ 专静㑊 } & \multirow{2}{*}{ (I) } & 31 & 3.76 & $6.40 \sim 3.20$ & 58.58 & $121.60 \sim 12.80$ & 94.31 & $174.13 \sim 16.20$ \\
\hline & & & & (7) & $(4.34)$ & $(9.60 \sim 3.20)$ & $(54.94)$ & $(57.60 \sim 22.40)$ & $(81.43)$ & $(67.20 \sim 35.20)$ \\
\hline \multirow{2}{*}{2} & \multirow{2}{*}{\multicolumn{2}{|c|}{ " }} & \multirow{2}{*}{ (III) } & 31 & 17.16 & $39.57 \sim 3.20$ & 75.79 & $189.96 \sim 25.60$ & 155.63 & $.322 .00 \sim 41.60$ \\
\hline & & & & (6) & $(13.90)$ & $(23.74 \sim 3.20)$ & $(70.87)$ & $(94.98 \sim 28.80)$ & (142.34) & $(316.60 \sim 76.80)$ \\
\hline
\end{tabular}


(1589) - $147-$

\begin{tabular}{|c|c|c|c|c|c|c|c|c|}
\hline \multirow{2}{*}{3} & & 30 & 16.33 & $31.66 \sim 3.20$ & 97.50 & $158.30 \sim 32.00$ & 158.48 & $270.11 \sim 63.32$ \\
\hline & & (5) & (11.52) & $(22.40 \sim 3.20)$ & $(70.40)$ & $(96.00 \sim 32.00)$ & $(118.20)$ & $(221.62 \sim 64.00)$ \\
\hline \multirow{2}{*}{4} & \multirow{2}{*}{$"$} & 30 & 12.89 & $25.60 \sim 3.20$ & 95.21 & $158.30 \sim 32.00$ & 170.11 & $300.77 \sim 84.00$ \\
\hline & & (5) & $(18.53)$ & $(25.60 \sim 3.20)$ & $(87.04)$ & $(128.00 \sim 32.00)$ & $(201.53)$ & $(270.11 \sim 142.47)$ \\
\hline \multirow{2}{*}{5} & \multirow{2}{*}{ 尺側皮静脉（I） } & 30 & 12.86 & $46.40 \sim 3.20$ & 73.82 & $77.10 \sim 32.00$ & 135.05 & $279.54 \sim 63.32$ \\
\hline & & (6) & $(15.40)$ & $(38.40 \sim 3.20)$ & $(70.40)$ & $(128.00 \sim 32.00)$ & (143.01) & $(158.30 \sim 32.00)$ \\
\hline \multirow{2}{*}{6} & \multirow{2}{*}{$"$} & 31 & 18.80 & $47.49 \sim 3.20$ & 91.35 & $189.96 \sim 32.00$ & 141.01 & $253.28 \sim 48.00$ \\
\hline & & (8) & $(22.56)$ & $(36.80 \sim 3.20)$ & $(73.07)$ & $(110.81 \sim 38.40)$ & (141.99) & $(216.00 \sim 57.60)$ \\
\hline \multirow{2}{*}{7} & \multirow{2}{*}{$"$} & 23 & 11.37 & $31.66 \sim 3.20$ & 71.96 & $126.64 \sim 41.60$ & 189.08 & $284.96 \sim 35.20$ \\
\hline & & $(8)$ & $(8.96)$ & $(16.00 \sim 3.20)$ & $(60.00)$ & $(112.00 \sim 19.20)$ & (138.85) & $(205.79 \sim 51.20)$ \\
\hline \multirow{2}{*}{8} & \multirow{2}{*}{$"$} & 24 & 11.06 & $25.60 \sim 3.20$ & 78.83 & $189.96 \sim 22.40$ & 135.36 & $237.45 \sim 48.00$ \\
\hline & & (6) & $(9.04)$ & $(19.20 \sim 3.20)$ & $(49.35)$ & $(79.15 \sim 19.20)$ & $(102.71)$ & $(132.36 \sim 60.80)$ \\
\hline \multirow{2}{*}{9} & \multirow{2}{*}{ 肘正 中皮静脉 } & 32 & 14.87 & $25.60 \sim 3.20$ & 83.34 & $189.96 \sim 32.00$ & 136.75 & $284.94 \sim 47.49$ \\
\hline & & (8) & $(10.77)$ & $(16.00 \sim 3.20)$ & $(88.52)$ & $(108.80 \sim 28.80)$ & $(172.54)$ & $(237.45 \sim 51.20)$ \\
\hline \multirow{2}{*}{10} & \multirow{2}{*}{ 前腕正中皮静脉 } & 28 & 7.63 & $15.83 \sim 3.20$ & 65.90 & $189.96 \sim 19.20$ & 149.25 & $237.45 \sim 48.00$ \\
\hline & & (5) & $(6.08)$ & $(12.80 \sim 3.20)$ & $(35.76)$ & $(48.00 \sim 9.60)$ & (126.73) & $(184.65 \sim 57.60)$ \\
\hline \multirow{2}{*}{11} & \multirow{2}{*}{ 背 例 中手静 脉 } & 24 & 9.49 & $23.70 \sim 3.20$ & 89.74 & $174.13 \sim 23.74$ & 108.66 & $221.62 \sim 51.20$ \\
\hline & & (5) & $(13.76)$ & $(22.40 \sim 3.20)$ & $(60.68)$ & $(96.00 \sim 22.40)$ & $(112.34)$ & $(174.13 \sim 71.23)$ \\
\hline \multirow{2}{*}{12} & \multirow{2}{*}{ 固有背側指静脉 } & 20 & 7.51 & $23.74 \sim 3.20$ & 63.08 & $126.64 \sim 14.40$ & 92.51 & $112.00 \sim 32.00$ \\
\hline & & (4) & $(9.60)$ & $(16.00 \sim 3.20)$ & $(63.20)$ & $(96.00 \sim 22.40)$ & $(60.58)$ & $(128.00 \sim 35.20)$ \\
\hline \multirow{2}{*}{13} & & 28 & 5.54 & $15.83 \sim 3.20$ & 65.11 & $158.30 \sim 19.20$ & 129.82 & $284.91 \sim 57.60$ \\
\hline & 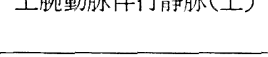 & (5) & $(4.48)$ & $(9.60 \sim 3.20)$ & $(46.11)$ & $(71.23 \sim 25.60)$ & $(95.02)$ & $(126.6+\sim 54.40)$ \\
\hline $1+$ & " & 16 & 8.00 & $12.80 \sim 3.20$ & 57.60 & $96.00 \sim 32.00$ & 115.72 & $128.65 \sim 64.00$ \\
\hline & (上) & $(0)$ & & & & & & \\
\hline 15 & (下) & 29 & 4.60 & $16.00 \sim 3.20$ & 57.97 & $126.64 \sim 27.40$ & 99.38 & $205.79 \sim 39.50$ \\
\hline & & (4) & $(4.00)$ & $(6.40 \sim 3.20)$ & $(33.71)$ & $(39.50 \sim 31.66)$ & (58.33) & $(79.15 \sim 47.49)$ \\
\hline 16 & (下) & 14 & 4.80 & $6.40 \sim 3.20$ & 36.10 & $126.64 \sim 16.00$ & 107.17 & $110.81 \sim 48.00$ \\
\hline & (下) & $(0)$ & & & & & & \\
\hline 17 & 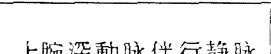 & 22 & & $16.00 \sim 3.20$ & 41.52 & $79.15 \sim 16.00$ & 68.16 & $142.47 \sim 16.00$ \\
\hline 16 & 上肊深動脉伴行解脉 & (4) & $(3.20)$ & $(15.83 \sim 3.20)$ & $(20.67)$ & $(55.40 \sim 16.00)$ & $(27.71)$ & $(31.66 \sim 22.40)$ \\
\hline 18 & " & 15 & 3.43 & $4.80 \sim 3.20$ & 28.96 & $55.40 \sim 12.80$ & 44.27 & $79.15 \sim 22.40$ \\
\hline 10 & " & (1) & $(3.20)$ & $(3.20)$ & $(23.70)$ & $(23.70)$ & $(20.59)$ & $(20.59)$ \\
\hline 19 & 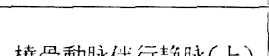 & 27 & 6.06 & $16.00 \sim 3.20$ & 53.21 & $110.81 \sim 12.80$ & 84.63 & $174.13 \sim 19.20$ \\
\hline 19 & 筧骨坋脉伴仃静脉(上) & (5) & $(6.37)$ & $(15.83 \sim 3.20)$ & $(57.97)$ & $(126.00 \sim 25.60)$ & (74.13) & $(142.47 \sim 32.00)$ \\
\hline 20 & & 17 & 4.80 & $9.60 \sim 3.20$ & 42.41 & $79.15 \sim 16.00$ & 58.47 & $126.64 \sim 25.00$ \\
\hline 20 & (E) & (1) & $(3.20)$ & $(3.20)$ & $(32.00)$ & $(32.00)$ & $(38.40)$ & $(38.40)$ \\
\hline 21 & 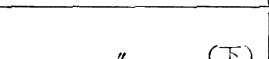 & 27 & 5.70 & $15.83 \sim 3.20$ & 50.39 & $158.30 \sim 12.80$ & 52.77 & $189.96 \sim 16.00$ \\
\hline 21 & $"$ & (5) & $(4.16)$ & $(6.40 \sim 3.20)$ & $(32.44)$ & $(48.00 \sim 16.00)$ & $(39.56)$ & $(64.00 \sim 22.40)$ \\
\hline
\end{tabular}




\begin{tabular}{|c|c|c|c|c|c|c|c|c|}
\hline \multirow{2}{*}{22} & \multirow{2}{*}{$" \quad$ (下) } & 19 & 6.13 & $15.83 \sim 3.20$ & 42.42 & $126.64 \sim 12.80$ & 47.48 & $84.40 \sim 16.00$ \\
\hline & & (3) & $(3.20)$ & $(3.20)$ & $(20.88)$ & $(24.00 \sim 16.00)$ & $(39.32)$ & $(54.00 \sim 19.20)$ \\
\hline \multirow{2}{*}{23} & \multirow{2}{*}{ 尺畄動永伴行静脉（上） } & 27 & 6.56 & $15.83 \sim 3.20$ & 53.71 & $126.64 \sim 12.80$ & 81.65 & $189.96 \sim 25.60$ \\
\hline & & $(4)$ & $(4.00)$ & $(6.40) \sim 3.20)$ & $(27.20)$ & $(48.00 \sim 12.80)$ & $(51.41)$ & $(96.00 \sim 25.60)$ \\
\hline \multirow{2}{*}{24} & \multirow{2}{*}{$"$ （上） } & 17 & 4.98 & $9.60 \sim 3.20$ & 36.35 & $80.00 \sim 12.80$ & 69.59 & $142.45 \sim 25.60$ \\
\hline & & $(2)$ & $(3.20)$ & $(3.20)$ & $(14.40)$ & $(16.00 \sim 12.80)$ & $(56.00)$ & $(86.40 \sim 25.60)$ \\
\hline \multirow{2}{*}{25} & \multirow{2}{*}{$" \quad(F)$} & 27 & 4.07 & $9.60 \sim 3.20$ & 42.59 & $89.00 \sim 19.20 \mid$ & 54.96 & $110.81 \sim 15.83$ \\
\hline & & $(4)$ & $(4.00)$ & $(6.40) \sim 3.20)$ & $(24.55)$ & $(38.40 \sim 28.81)$ & $(32.55)$ & $(41.60 \sim 19.20)$ \\
\hline \multirow{2}{*}{26} & \multirow{2}{*}{$"$ (下) } & 18 & 3.73 & $6.40 \sim 3.20$ & 36.31 & $64.00 \sim 16.00$ & 35.09 & $54.00 \sim 25.00$ \\
\hline & & (1) & $(3.20)$ & $(3.20)$ & $(28.80)$ & $(28.80)$ & $(32.00)$ & $(32.00)$ \\
\hline \multirow{2}{*}{27} & \multirow{2}{*}{ 総骨間動脉伴行青冰脉 } & 23 & 4.44 & $9.60 \sim 3.20$ & 28.97 & $63.32 \sim 12.80$ & 47.59 & $142.47 \sim 22.40$ \\
\hline & & $(3)$ & $(4.20)$ & $(9.60) \sim 3.20)$ & $(28.80)$ & $(38.40 \sim 22.40)$ & $(43.30)$ & $(54.40 \sim 41.60)$ \\
\hline \multirow{2}{*}{28} & \multirow{2}{*}{$"$} & 19 & 4.57 & $6.40 \sim 3.20$ & 26.90 & $47.49 \sim 12.80$ & 55.63 & $96.00 \sim 22.40$ \\
\hline & & $(3)$ & $(5.33)$ & $(6.40) \sim 3.20)$ & $(25.60)$ & $(32.00 \sim 22.40)$ & $(41.60)$ & $(48.00 \sim 25.60)$ \\
\hline \multirow{2}{*}{29} & \multirow{2}{*}{ 浅学 静 䐂 弓 } & 23 & 3.41 & $6.40 \sim 3.20$ & 29.90 & $63.32 \sim 16.00$ & 54.27 & $104.07 \sim 16.00$ \\
\hline & & $(2)$ & $(3.20)$ & $(3.20)$ & $(24.80)$ & $(32.00 \sim 17.60)$ & $(29.60)$ & $(32.00 \sim 27.20)$ \\
\hline \multirow{2}{*}{30} & \multirow{2}{*}{$"$} & 17 & 3.20 & $3.20 \sim 3.20$ & 21.23 & $32.00 \sim 12.80$ & 37.09 & $91.44 \sim 12.80$ \\
\hline & & (2) & $(3.20)$ & $(3.20 \sim 3.20)$ & $(15.20)$ & $(16.00 \sim 14.40)$ & $(33.60)$ & $(38.40 \sim 28.80)$ \\
\hline \multirow{2}{*}{31} & \multirow{2}{*}{ 深学静脉 弓 } & 21 & 5.16 & $11.20 \sim 3.20$ & 47.20 & $80.00 \sim 16.00$ & 71.03 & $106.60 \sim 28.80$ \\
\hline & & (3) & $(6.27)$ & $(9.60) \sim 3.20)$ & $(33.60)$ & $(64.00 \sim 16.00)$ & $(67.13)$ & $(135.59 \sim 19.20)$ \\
\hline \multirow{2}{*}{32} & \multirow{2}{*}{$"$} & 13 & 5.60 & $6.40 \sim 3.20$ & 46.40 & $80.00 \sim 25.60$ & 60.80 & $98.60 \sim 25.60$ \\
\hline & & (1) & $(6.40)$ & $(6.40)$ & $(48.80)$ & $(48.80)$ & $(103.10)$ & $(103.10)$ \\
\hline \multirow{2}{*}{33} & \multirow{2}{*}{ 統 学 指 静 脉 } & 16 & 3.42 & $4.80 \sim 3.20$ & 31.43 & $48.00 \sim 19.20$ & 30.13 & $54.40 \sim 15.83$ \\
\hline & & $(3)$ & $(3.20)$ & $(3.20)$ & $(26.67)$ & $(44.80 \sim 12.80)$ & $(27.73)$ & $(51.20 \sim 12.80)$ \\
\hline \multirow{2}{*}{34} & \multirow[t]{2}{*}{$"$} & 15 & 3.43 & $4.80 \sim 3.20$ & 22.36 & $38.40 \sim 12.00$ & 21.03 & $41.60 \sim 12.80$ \\
\hline & & (2) & $(3.20)$ & $(3.20 \sim 3.20)$ & $(24.00)$ & $(41.60 \sim 6.40)$ & $(24.00)$ & $(41.60 \sim 6.40)$ \\
\hline \multirow{2}{*}{35} & \multirow{2}{*}{ 固有掌侧指临脉 } & 17 & 3.20 & $3.20 \sim 3.20$ & 16.17 & $31.66 \sim 9.6$ & 25.42 & $79.15 \sim 9.60$ \\
\hline & & $(2)$ & $(4.00)$ & $(4.80 \sim 3.20)$ & $(19.70)$ & $(26.60 \sim 12.80)$ & $(25.90)$ & $(32.00 \sim 19.80)$ \\
\hline \multirow{2}{*}{36} & \multirow[t]{2}{*}{ " } & 17 & 3.20 & $3.20 \sim 3.20$ & 17.26 & $25.60 \sim 12.80$ & 20.93 & $55.40 \sim 12.80$ \\
\hline & & (1) & $(3.20)$ & $(3.20)$ & $(6.40)$ & $(6.40)$ & $(9.60)$ & $(9.60)$ \\
\hline
\end{tabular}

\section{2. 年令亡内・中・外膜各層壁厚亡の関係}

この関倸を知るため，人生期別に抜粋せる主要静脉 の平均值を表 9 に掍げる。内膜に抢いて一部動脉同様 の傾向京るものを認めるも，全作としては著しい差異 を恐め得ない。中膜に颃いては第四成熟期又は第一老 年期まで溸增し、第二老年期にいたりて幾分減少する 傾向があるように思われる。外膜に执いても中膜ほど

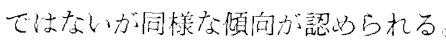

以上の事より静脉管の基礎は中膜なりと思考する。

\section{iv. 上肢静脉管の組織学的構造}

内膜は単層扁平上皮の内皮及び内皮下結合組織の薄 層上りなり, ま饥に内縦走筋及び点状の縦走弾性線維 及び, ラセン状の輪走弾性線維（以下弾性線維を $\mathrm{EF}$ と記す) 老認め内弾性板は一部不完全ながらも認めら れる。中膜は主として輪走滑平筋よりなり(一部斜走) 動脉に比較すれば発育はや」不良なるも皮静脉にいた りては, 或程度良好である。筋線熦間に主として縱走 する EF を锠める。外膜は主として結合組織よりな 
表 9. 上肢静脉管の人生期別内. 中. 外膜各層壁厚の平均值 (今)

\begin{tabular}{|c|c|c|c|c|c|c|c|c|c|c|c|c|c|c|c|c|}
\hline \multirow{2}{*}{ 層| } & \multirow{2}{*}{ No. } & \multirow{2}{*}{ 静 } & \multicolumn{2}{|c|}{ 青 年 期 } & \multicolumn{2}{|c|}{ 第一成熟期 } & \multicolumn{2}{|c|}{ 第二成熟期 } & \multicolumn{2}{|c|}{ 第三成熟期 } & \multicolumn{2}{|c|}{ 第四成熟期 } & \multicolumn{2}{|c|}{ 第一老年期 } & \multicolumn{2}{|c|}{ 第二老年期 } \\
\hline & & & $\mathrm{N}$ & M & $N$ & M & $\mathrm{N}$ & M & $\mathrm{N}$ & M & $\mathrm{N}$ & M & $\mathrm{N}$ & M & $\mathrm{N}$ & M \\
\hline \multirow{10}{*}{ 内 } & 1 & 橈側皮静脉（I） & 1 & 3.20 & 9 & 3.37 & 5 & 3.20 & 4 & 4.60 & 4 & 3.62 & 4 & 4.28 & 4 & 4.28 \\
\hline & 3 & 橈側皮静脉（IV) & 1 & 15.83 & 9 & 16.54 & 4 & 18.25 & 4 & 14.40 & 4 & 17.68 & 4 & 12.92 & 4 & 18.06 \\
\hline & 5 & 尺側皮静脉（I） & 1 & 12.80 & 9 & 11.30 & 5 & 7.60 & 5 & 21.56 & 3 & 8.53 & 4 & 17.55 & 3 & 9.92 \\
\hline & 7 & 尺側皮静脉（III） & 1 & 12.80 & 6 & 10.11 & 3 & 20.15 & 5 & 6.56 & 2 & 10.49 & 2 & 12.89 & 4 & 12.04 \\
\hline & 9 & 肘 正中皮静脉 & 1 & 7.91 & 9 & 18.61 & 5 & 14.01 & 5 & 12.80 & 4 & 14.92 & 2 & 12.64 & 4 & 14.07 \\
\hline & 11 & 背 例 中手静脉 & 1 & 8.00 & 6 & 10.83 & 4 & 10.80 & 3 & 11.68 & 4 & 7.15 & 4 & 9.49 & 2 & 12.66 \\
\hline & 12 & 固有背側指静脉 & 1 & 3.20 & 6 & 5.36 & 4 & 6.95 & 3 & 7.73 & 2 & 7.76 & 2 & 8.56 & 2 & 15.62 \\
\hline & 13 & 上腕動脉伴行青争脉 (上) & 1 & 3.20 & 8 & 6.58 & 5 & 4.48 & 5 & 5.73 & 3 & 4.77 & 4 & 7.15 & 2 & 7.57 \\
\hline & 17 & 上腕媣動脉伴行静脉 & 1 & 3.20 & 6 & 5.57 & 4 & 3.20 & 4 & 3.20 & 3 & 3.20 & 2 & 4.80 & 2 & 5.37 \\
\hline & 19 & 橈骨動脉伴行青筝脉(上) & 1 & 6.40 & 7 & 3.20 & 3 & 5.34 & 5 & 4.52 & 3 & 7.47 & 4 & 11.03 & 4 & 6.61 \\
\hline \multirow{5}{*}{ 膜 } & 23 & 尺骨動脉伴行静脉 (上) & 1 & 12.80 & 7 & 6.59 & 3 & 4.27 & 5 & 4.96 & 3 & 4.80 & 4 & 10.44 & 4 & 6.10 \\
\hline & 27 & 釉骨間動脉伴行静脉 & 1 & 6.40 & 6 & 3.88 & 3 & 3.20 & 4 & 6.58 & 3 & 2.68 & 4 & 4.62 & 2 & 3.50 \\
\hline & 29 & 浅 掌 静 脉 弓 & 1 & 3.20 & 6 & 3.32 & 3 & 3.20 & 4 & 6.40 & 3 & 3.27 & 4 & 4.16 & 2 & 3.30 \\
\hline & 31 & 深 掌 静 脉 弓 & 1 & 3.20 & 6 & 4.51 & 3 & 4.12 & 4 & 5.78 & 2 & 8.18 & 2 & 5.78 & 2 & 4.76 \\
\hline & 35 & 固有掌側指静脉 & 1 & 3.20 & 4 & 3.20 & 3 & 3.20 & 3 & 3.20 & 3 & 3.20 & 2 & 3.20 & 2 & 3.20 \\
\hline \multirow{15}{*}{ 中 } & 1 & 筧側皮静脉 (I) & 1 & 70.00 & 9 & 62.09 & 5 & 40.51 & 4 & 42.13 & 4 & 83.51 & 4 & 64.49 & 4 & 55.44 \\
\hline & 3 & 橈側皮静脉（IV) & 1 & 118.47 & 9 & 90.28 & 4 & 93.63 & 4 & 00 & 4 & 93.38 & 4 & 96.30 & 4 & 113.57 \\
\hline & 5 & 尺勋皮竫脉（I） & 1 & 69.40 & 9 & 78.28 & 5 & 54.92 & 5 & 87.26 & 3 & 97.60 & 4 & 79.02 & 3 & 68.65 \\
\hline & 7 & 尺側皮静脉（III） & 1 & 79.15 & 6 & 68.99 & 3 & 65.79 & 5 & 65.51 & 2 & 83.98 & 2 & 73.47 & 4 & 75.56 \\
\hline & 9 & 时正中皮静脉 & 1 & 61.24 & 9 & 78.87 & 5 & 86.58 & 5 & 87.45 & 4 & 84.82 & 2 & 108.99 & 4 & 76.77 \\
\hline & 11 & 背 側 中手静脉 & 1 & 88.51 & 6 & 97.63 & 4 & 96.54 & 3 & 96.54 & 4 & 68.84 & 4 & 90.05 & 2 & 84.45 \\
\hline & 12 & 固有背側指静脉 & 1 & 52.00 & 6 & 52.78 & 4 & 59.94 & 3 & 85.26 & 2 & 63.90 & 2 & 71.12 & 2 & 79.03 \\
\hline & 13 & 上帵動脉伴行静脉(上) & 1 & 32.40 & 8 & 76.24 & 5 & 46.62 & 5 & 48.30 & 3 & 89.15 & 4 & 72.15 & 2 & 75.05 \\
\hline & 17 & 上腕媣動脉伴行静脉 & 1 & & 6 & 47.56 & 4 & 28.63 & 4 & 32.25 & 3 & 42.38 & 2 & 54.60 & 2 & 51.16 \\
\hline & 19 & 橈盈動脉伴行静脉（上） & 1 & 40.00 & 7 & 50.00 & 3 & 39.47 & 5 & 56.59 & 3 & 47.55 & 4 & 64.42 & 4 & 51.24 \\
\hline & 23 & 尺骨動脉伴行静脉 (上) & 1 & 40.00 & 7 & 46.91 & 3 & 47.60 & 5 & 45.34 & 3 & 49.85 & 4 & 78.51 & 4 & 52.15 \\
\hline & 27 & 総骨間動脉伴行静脉 & 1 & 33.32 & 6 & 24.59 & 3 & 20.47 & 4 & 44.72 & 3 & 21.85 & 4 & 32.09 & 2 & 25.68 \\
\hline & 29 & 浅 堂 静 脉 弓 & 1 & 32.00 & 6 & 28.86 & 3 & 25.49 & 4 & 37.43 & 3 & 25.88 & 4 & 30.49 & 2 & 29.40 \\
\hline & 31 & 深 学 静 脉 弓 & 1 & 40.00 & 6 & 43.20 & 3 & 42.23 & 4 & 54.40 & 2 & 45.60 & 2 & 48.60 & 2 & 46.20 \\
\hline & 35 & 固有掌側指静脉 & 1 & 9.60 & 4 & 11.20 & 3 & 20.69 & 3 & 20.27 & 3 & 16.53 & 2 & 19.20 & 2 & 12.88 \\
\hline \multirow{10}{*}{ 外 } & 1 & 橈側皮静脉（I） & 1 & 104.40 & 9 & 134.65 & 5 & 97.82 & 4 & 107.72 & 4 & 75.34 & 4 & 73.73 & 4 & 73.06 \\
\hline & 3 & 撓則皮静脉（W） & 1 & 119.95 & 9 & 162.96 & 4 & 169.51 & 4 & 180.50 & 4 & 150.66 & 4 & 138.39 & 4 & 158.87 \\
\hline & 5 & 尺側皮静脉（I） & 1 & 154.50 & 9 & 121.50 & 5 & 163.21 & 5 & 124.89 & 3 & 91.28 & 4 & 161.48 & 3 & 113.80 \\
\hline & 7 & 尺側皮静脉（价） & 1 & 147.65 & 6 & 205.88 & 3 & 225.62 & 5 & 156.25 & 2 & 200.08 & 2 & 208.19 & 4 & 163.38 \\
\hline & 9 & 时 正 中皮静晾 & 1 & 120.81 & 9 & 135.58 & 5 & 185.54 & 5 & 131.17 & 4 & 109.29 & 2 & 114.58 & 4 & 124.76 \\
\hline & 11 & 背 側 中手静脉 & 1 & 75.38 & 6 & 93.43 & 4 & 66.79 & 3 & 161.56 & 4 & 123.49 & 4 & 108.35 & 2 & 133.48 \\
\hline & 12 & 固有背側指静脉 & 1 & 72.80 & 6 & 88.09 & 4 & 82.72 & 3 & 95.20 & 2 & 132.04 & 2 & 136.93 & 2 & 81.88 \\
\hline & 13 & 上腕動脉伴行静脉(上) & 1 & 143.55 & 8 & 146.34 & 5 & 119.86 & 5 & 101.10 & 3 & 117.67 & 4 & 140.12 & 2 & 144.76 \\
\hline & 17 & 上腕媣動脉伴行静脉 & 1 & 51.27 & 6 & 100.61 & 4 & 51.55 & 4 & 46.36 & 3 & 66.58 & 2 & 61.36 & 2 & 66.08 \\
\hline & 19 & 橈骨動脉伴行静脉(上) & 1 & 67.73 & 7 & 74.94 & 3 & 75.46 & 5 & 87.47 & 3 & 104.95 & 4 & 93.46 & 4 & 83.44 \\
\hline \multirow[t]{5}{*}{ 膜 } & 23 & 尺具動脉伴行静脉 (上) & 1 & 70.65 & 7 & 65.56 & 3 & 106.21 & 5 & 56.96 & 3 & 114.49 & 4 & 104.70 & 4 & 72.21 \\
\hline & 27 & 釉吾間動脉伴行静脉 & 1 & 51.18 & 6 & 46.80 & 3 & 55.73 & 4 & 48.91 & 3 & 44.80 & 4 & 48.59 & 2 & 36.92 \\
\hline & 29 & 浅 掌 静 脉 弓 & 1 & 32.00 & 6 & 55.14 & 3 & 45.16 & 4 & 53.35 & 3 & 46.67 & 4 & 65.60 & 2 & 43.14 \\
\hline & 31 & 染 掌 静 脉 弓 & 1 & 64.80 & 6 & 68.82 & 3 & 64.14 & 4 & 85.01 & 2 & 63.32 & 2 & 78.32 & 2 & 72.44 \\
\hline & 35 & 固有掌側指静脉| & 1 & 6.40 & 4 & 15.60 & 2 & 55.52 & 3 & 29.86 & 3 & 20.60 & 2 & 32.00 & 2 & 20.72 \\
\hline
\end{tabular}

り,縦走筋及び斜走傾向強き縦走筋と血管·神経及び輪 走傾向強き EF を諰める。(外弹性板は全く認め得ず) 以下上肢静脉の部位的, 年令的变化を内 -中 · 外膜の
順に全例中より抜枠，逐次記述することにする。記載 にあたり次の略号を使用する。
a）澱，淡は染色の度合を示し記載無きは中染 
$-150-(1592)$

b) EF は弾性線雜を表わし，EF の形状は線状， 綿状, ラ状 (ラセ之状), 点状の 4 種とし（）内の I II IIIはラ状の大きさを表わし I $<$ II < III とする。

c） MF は筋線維を表わす。

d） L MF は綐走筋線維を表わす。

\section{A.内膜}

動脉に関寸る先人の研究によれば末梢ほよ゙年令的変 化（增殖，肥厚，硬変）を生じや寸く，しか子その変 化は逐年令的に，末梢部より中心部に向うことが知ら れている。著者为様なる変化をある程度期待しつ」 観察を行つたが，確然たるものは認められなかつた。 ただ时. 䛷両関䬣部（特に时関接部皮下）附近におい

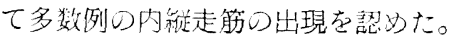

1）橈側皮静脉一上踠部

内皮細胞に治つて発育の㦞い内弾性板様のラ状 ( I , II) EF を大多数に認める。中膜側密, 末れに内皮下に 細点状EF歹り，な括 $\mathrm{LMF}$ は中心方には見当らない が末梢方にて22才，25才，27才，34才，40才，44才， 50 才， 60 才， 74 才に現われる。年令的変化不著明。

3）橈側皮静脉一前踠部

1)とほが同様なるも, 内弾性板様 EF の外, 内皮 下に不規則点状のEF荥り。中心方には 22才，25才， 27才，30才，50才，60才，61才，71才に LMFを認 め, 未梢方には認めら机ない。年令的变化不著明。

5) 尺側皮静脉一上腕部

1)，3）上り出現度は少ないが，ラ状（IまれにII) の内弾性板樣 EF むり，60 才位志では不変で岕るが 70 才頃上り幾分薄く侈くなるように思わ机る。なお 34才，50才，61才，71才に LMF हैり。

7) 尺側皮静脉一前腕部

的皮細胞に沿つて弱いラ状（I れれ II） EF を1 〜2 条, 時として壁厚の大なる部分に柾なる不規則点 状のEF あり，22才，40才，71才に LMFを認めた。 年令的変化は 5) と同様なり。

12) 固有背側指静脉

内皮細胞に治つて 33 才以外の各年令に濃亏状(II) 一部にラ状 (且) の EF あり, LMF 及び年令的変化 不著明。

\section{3)上腕動脉伴行静脉}

内皮細胞に治つて, 線状, ラ状 (I), 及び点状の $\mathrm{EF}$ 䘮46才，50才，60才，74才に断続的に，他の年令 に連統して認める: 71 才に LMF あり, 年令的変化 不著明。

\section{9）暁骨動脉伴行静脉}

19 才では淡う状（I）の弱いEF あり。二の他は 26才，28才，40才，49才，50才，74才に断続しその他 の年令に連続せるや〉浱ラ状（III）のEFを内弾性板 様に認める。71才に LMF あり。年令的変化は不著 明。

23） 尺肯動脉伴行静脉

内皮細胞に浻つて 24 才，27才，44才，46才，49才， 76才に点状, 細い浱亏状（I）のEFを，天の他の年 令に濃ラ状 (I，II) DEF を連続して涩める。40才， 60 才に LMF 走認めるも年令的変化は不著明。

\section{9）浅掌静脉引}

内皮細胞に治つてや小濃染せるラ状（I）及び点状 のEFを24才，28才，50才，60才，71才，72才に一 部断続して,ての他の年令にや小偝染せるラ状 (II , III) の $\mathrm{EF}$ を連続して認める。 $\mathrm{LMF}$, 年令的変化とるに 不著明。

(附) 深掌静脉引の内膜は大部分収縮届曲が強く一見 肥厚のように見える。

35) 固有掌唰指静脉

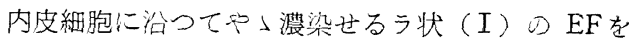
24才，28才，44才，50才，60才，72才に認め，25才， 27 才，33才，34才，40才，42才，46才，62才，74才に 細ラ状（ＩII まれにIII）の EF を連続して認めた。 $\mathrm{LMF}$ ，年令的变化上军不著明。

\section{B. 中 膜}

動脉に比較すれば薄弱なるも，中膜の主構成要素た る平滑筋線維及び弾性線維，結合組織線維よりなる， 平滑筋は主として輪走す(約 2,000 例中, 斜走傾向強 き电の57 例, 走行不定のbの 5 例, 轵走筋の混在せ るもの1例, 他は全郆, 翰走す)。個々の筋層の厚さは 皮下静脉り方が大なるも, 全壁厚との割合より見れば， 深静脉の方が皮下静脉より筋量大である。また両者と も末梢ほど脉管の太さに比し筋量大となり，EF の量 も之に比例するように思われる。これらの成績は先人 の報告とよく一致するところである。EF \& $\mathrm{MF}$ 閻に 淡ラ状（I）のもの主とし之に中染せる点状, 線状, ラ状（I.II まれにIII）の EF あり。部位的に縦走傾 向強く、これを柵状に僅少の輪走 EF が結っ゙ものと思 われる。掌側中手, 背侧中手では輪走傾向強く，橈测 皮, 背側指では幾分輪走傾向が強いように思われる 年令的には EFは30才位までは質量共に増加，その 後は量的変化は少ないが，中に配列の幾分不規則なる ものあり。70 才位より質量ともに変化し，EF も幾 
表 10. 年令別上肢静脉管中膜の変化

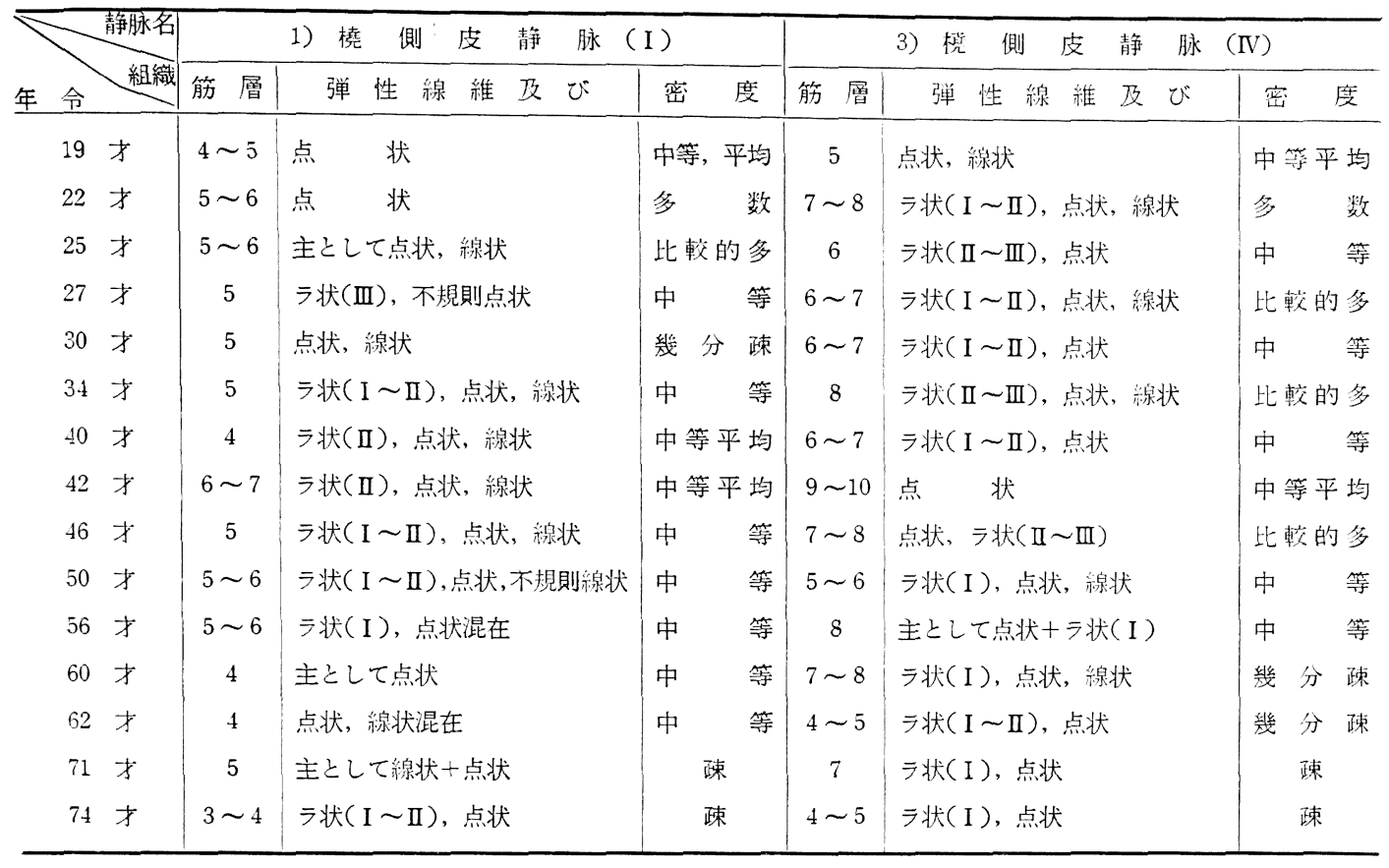

(その2)

\begin{tabular}{|c|c|c|c|c|c|c|c|c|c|}
\hline \multirow[b]{2}{*}{ 年 } & 静脉名 & \multicolumn{4}{|c|}{ 5) 尺側皮静脉 (I) } & \multicolumn{4}{|c|}{ 7) 尺側 皮静 脉 (III) } \\
\hline & 組織 & 筋 層 & 弾 性線 維 及び & 密 & 度 & 筋 層 & 弾性線維 及。゙ & 密 & 度 \\
\hline 19 & 才 & 6 & 点状, ラ状 $(\mathrm{I} \sim \mathrm{II})$ & 中 & 平均 & 6 & 点状, 細ラ状( I ) & 中等三 & F均 \\
\hline 22 & 才 & 6 & ラ状 $(I ＼mathrm{~ I I ~})$ +点状 & 比 & 的多 & 6 & 点状, ラ状 $(\mathrm{I} \sim \mathrm{II})$, 線状 & 中 & 等 \\
\hline 25 & 才 & $5 \sim 6$ & ラ状( I ), 点状 & 比 & 的多 & 6 & ラ状 $(\mathrm{I} \sim \mathrm{II})$, 点状 & 比較白 & 勺多 \\
\hline 27 & 才 & $4 \sim 5$ & 点状, ラ状 (I) & 中 & 平均 & $6 \sim 7$ & F状 $(\mathrm{I} \sim \mathrm{II})$, 点状 & 比較白 & 勺多 \\
\hline 30 & 才 & $5 \sim 6$ & ラ状 $(I)$, 点状 & 比 & 的多 & 5 & ラ状 $(\mathrm{I} \sim \mathrm{II})$, 点状 & 中 & 等 \\
\hline 34 & 才 & $6 \sim 7$ & ラ状(II), 線状, 点状 & 比 & 的多 & $7 \sim 8$ & 点状, ラ状 $(\mathrm{I} \sim \mathrm{II})$, 線状 & 多 & 数 \\
\hline 40 & 才 & $6 \sim 7$ & ラ状 $(\mathrm{I} \sim \mathrm{II}$, 稀にIII), 点状 & 比 & 的多 & 7 & 点状, ラ状 $(\mathrm{I} \sim \mathrm{II})$ & 中 & 等 \\
\hline 42 & 才 & $7 \sim 11$ & 点状 & 中 & 等 & $7 \sim 9$ & 主として点状+ラ状 $(\mathrm{I} \sim \mathrm{II})$ & 比䡆白 & 多 \\
\hline 46 & 才 & 5 & ラ状( I ), 点状 & 中 & 等 & $5 \sim 6$ & ラ状( I 〜 II)点状, 線状 & 中 & 等 \\
\hline 50 & 才 & 7 & ラ状 $(I \sim I I)$, 点状 & 中 & 等 & $6 \sim 7$ & 点状，線状，ラ状( I 〜 II) & 中 & 等 \\
\hline 56 & 才 & $6 \sim 7$ & 点状, 線状 & 中 & 等 & 8 & 主として点状, 一部ラ状 ( I ) & 中 & 等 \\
\hline 60 & 才 & 7 & ラ状 $(I \sim I I)$, 点状, 線状 & 中 & 等 & 6 & $\begin{array}{l}\text { 主として点状, 線状, 一部ラ状 } \\
\text { (I〜五) }\end{array}$ & 中 & 等 \\
\hline 62 & 才 & 6 & ラ状 $(\mathrm{I} \sim \mathrm{II})$, 点状, 線状 & 中 & 等 & 6 & 中線状，ラ状（I～II ) & 幾 分 & \\
\hline 71 & 才 & 6 & ラ状( I ), 点状 & & & 6 & ラ状 (I ), 点状 & 幾 分 & \\
\hline 74 & 才 & $5 \sim 6$ & ラ状(I), 点状, 線状 & & & 4 & 点状, 線状 & & 疎 \\
\hline
\end{tabular}




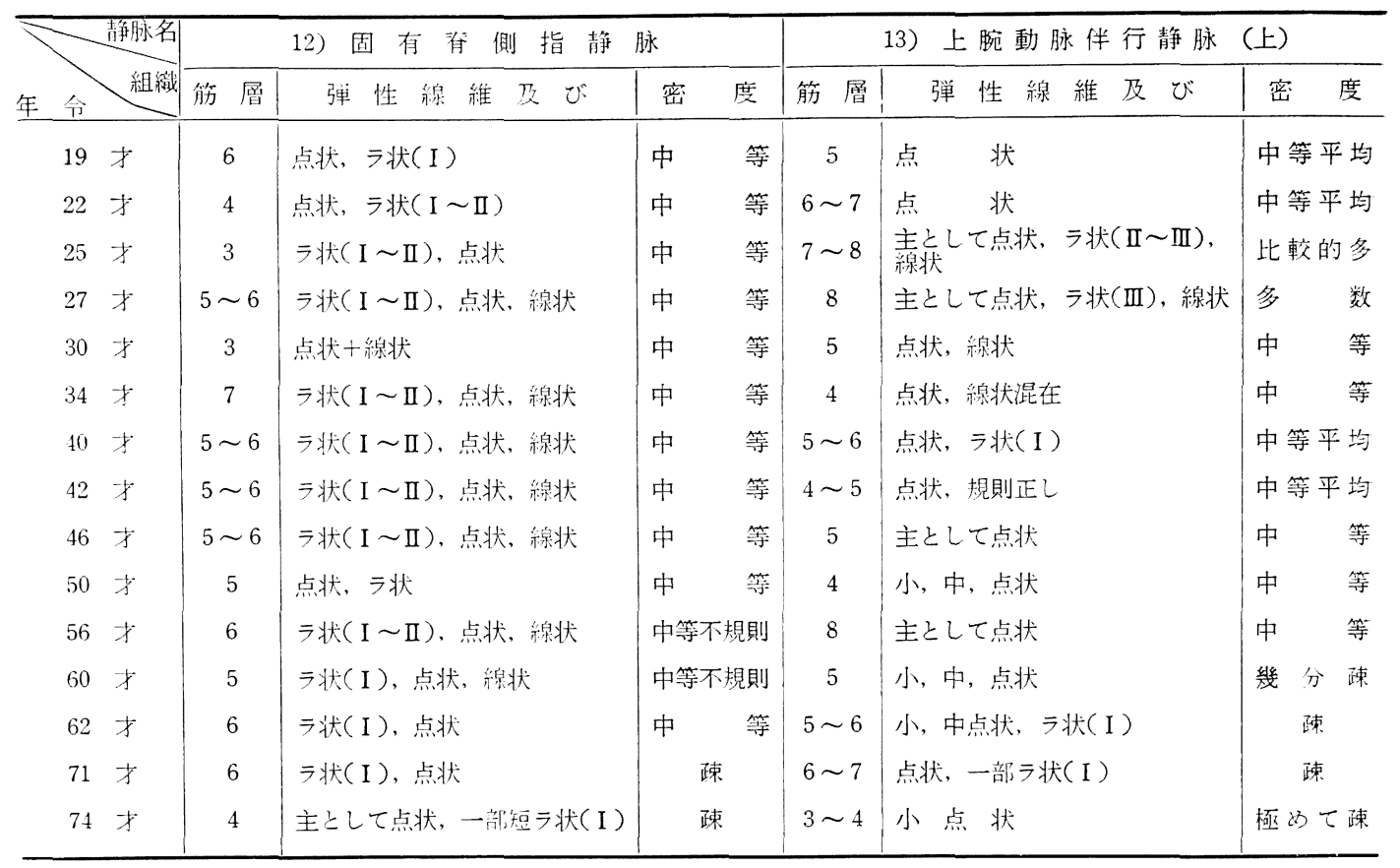

(その4)

\begin{tabular}{|c|c|c|c|c|c|c|c|}
\hline$\sigma$ & 青争脉名 & & 19）撓骨動脉伴行静脉 & （上） & & 23）尺骨動脉伴行静脉 & (上) \\
\hline 令 & 組織 & 筋 層 & 弾性線 維 及び & 度 & 筋 層 & 弾 性 線 維 及び & 密 \\
\hline 19 & $才$ & 3 & 状 & 中等平均 & 3 & 線 & 中等平均 \\
\hline 22 & 才 & $4 \sim 5$ & 中点状, ラ状 ( I ) & 比較的多 & $4 \sim 5$ & 主として細線状十小点状 & 比較的多 \\
\hline 25 & 才 & $5 \sim 6$ & 小点状, ラ状 ( I ) & 等 & 4 & ラ状 (I), 点状 & 中 等 整 \\
\hline 27 & 才 & 5 & 小点状, 短線状. ラ状 $(\mathrm{I} \sim \mathrm{II})$ & 等 & 5 & 淡ラ状, ラ状 $(I \sim I I)$, 点状 & 比較的多 \\
\hline 30 & $才$ & $3 \sim 4$ & 細点状，細線状 & 等 & $3 \sim 4$ & 小点状. ラ状 ( I ) & 中 \\
\hline 34 & - & $3 \sim 4$ & 小点状，淡ラ状（I） & 中等 & 5 & ラ状 ( I 稀: こI), 点状 & 中 \\
\hline 40 & 才 & $3 \sim 4$ & 小点状, 淡ラ状( I ) & 中等平均 & 3 & 細点状，ラ状( I ) & 中 \\
\hline 42 & 才 & $4 \sim 5$ & 点状, 規則正し & 多数 & $3 \sim 4$ & 点状, 線状 & 比較的多 \\
\hline 46 & 文 & $5 \sim 6$ & 小, 中, 点状 & 比較的多 & 4 & 小点状, 線状 & \\
\hline 50 & $\dot{x}$ & $5 \sim 6$ & 小点状, ラ状( I 〜 I ) & 中等 & 5 & ラ状 $(I \sim I I)$, 点状 & 中 等 \\
\hline 56 & 苦 & 5 & 小点状, ラ状( I ) & 幾 分 疎 & $6 \sim 7$ & 淡線状，ラ状( I ) & 中. 等 \\
\hline 60 & 才 & 4 & 小点状, ラ状( I 〜 II ) & 幾 分 疎 & 4 & 小点状, ラ状( I ) & 中等不整 \\
\hline 62 & 才 & 5 & 小点状，線状，ラ状( I 〜 II ) & 虫 規 ${ }^{\text {等, }}$ 則 & 6 & 小, 中点状, ラ状 $(\mathrm{I} \sim \mathrm{II})$ & 中 \\
\hline 71 & 才 & 5 & 淡ラ状 (I), ラ状 (I), 点, 線状 & 幾 分 疎 & 4 & ラ状 $(I \sim I)$, 不規則点状 & 中 \\
\hline 74 & 才 & $3 \sim 4$ & ラ状( II), 稀に小点状 & 極的て柾 & $5 \sim 6$ & 点状, 細ラ状 & 幾 分 眯 \\
\hline
\end{tabular}


$(\because の 5)$

\begin{tabular}{|c|c|c|c|c|c|c|c|c|}
\hline S & 静脉名 & & 29）浅＼cjkstart掌 静 & 弓 & & & 35）固有掌側指 赩 & 脉 \\
\hline 年 令 & 組織 & 筋 啗 & 弾性線 維 及び & 密 & 变 & 筋 層 & 弾性線維 及び & 密 \\
\hline 19 & $x$ & 3 & 点＼cjkstart状 & 中等平土 & 均 & 3 & 点状 & 中 \\
\hline 22 & $x$ & 4 & 線状, 点状, ラ状 (I) & 中 等 束 & & 3 & 点状, ラ状 ( I ) & 中等 整 \\
\hline 25 & † & $3 \sim 4$ & 点状, ラ状( I ) & 中 & & 3 & ラ状( I ), 短酎状 & 比較的多 \\
\hline 27 & 才 & 4 & 小点状, ラ状(I), 浱ラ状 (I) & 中 & 等 & 3 & 中点状，短線就 & 中 等 \\
\hline 30 & 才 & 3 & ラ $\quad$ 状( I ) & 中等青 & 整 & 3 & ラ $\quad$ 状( I ) & 中 \\
\hline 34 & 才 & 3 & ラ $\quad$ 状( I ) & 中 & 等 & 3 & ラ $\quad$ 状 $(\mathrm{I})$ & 中等不整 \\
\hline 40 & 才 & 4 & 小点状, ラ状 ( I ) & 中 今 & 等 & 3 & 小点状, ラ状 ( I ) & 中 等 \\
\hline 42 & $\rtimes$ & $3 \sim 4$ & ラ $\quad$ 状 $(\mathrm{I})$ & 幾 分 $\overrightarrow{1}$ & 疎 & 3 & 小点状, ラ状 (I), 短線状 & 中等不整 \\
\hline 46 & 才 & $3 \sim 4$ & 点状, ラ状 (I) & 中 & 等 & 4 & 小点状, ラ状 ( I ) & 中 \\
\hline 50 & 才 & 3 & 点状, ラ状 (I) & 中 今 & 等 & 3 & ラ状(I), 小点状 & 中 \\
\hline 56 & $x$ & 3 & 中点状, ラ状( I ) & 幾 分政 & 疎 & 3 & ラ状(I), 小点状 & 中等不整 \\
\hline 60 & 才 & $3 \sim 4$ & 小, 中点状 & 中等不来 & & $3 \sim 4$ & ラ状 (I)，小点状 & 幾 分 疎 \\
\hline 62 & 才 & 3 & ラ状 $(I \sim \Pi)$, 点状, 短線状 & 中等不考 & & 4 & 小点状, 短ラ状 $(I \sim I I)$ & 幾 分 疎 \\
\hline 71 & 才 & 4 & ラ状 $(I 〜 I I)$, 点状 & 疎 & & 3 & ラ状 $(I ＼mathrm{~ I I ~), ~ 点 状 ~}$ & 幾 分 疎 \\
\hline 74 & X & $3 \sim 4$ & 細ラ状 $(I 〜 I I)$, 点状 & 幾 分 & 倵 & 3 & 小点状, ラ状( I ) & 疎 \\
\hline
\end{tabular}

分淡染し紐くなり，ラ状も小さく短かく，不規則また

は疎となる傾向が認められる。

以下個々の成績につき抜粋せるもの表 10 に揭げ

\section{C. 外膜}

動脉に比べ発育は良好である。結合組織，平滑筋よ

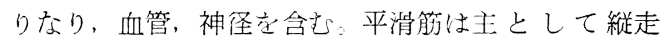
し，小血管を見る。EFは中膜のそれより粗大で不規 ๖

表 11. 年令別上肢静脉管外膜の変化 $(\mathrm{LMF}=$ 縦走筋, $\mathrm{G}=$ 小血管)

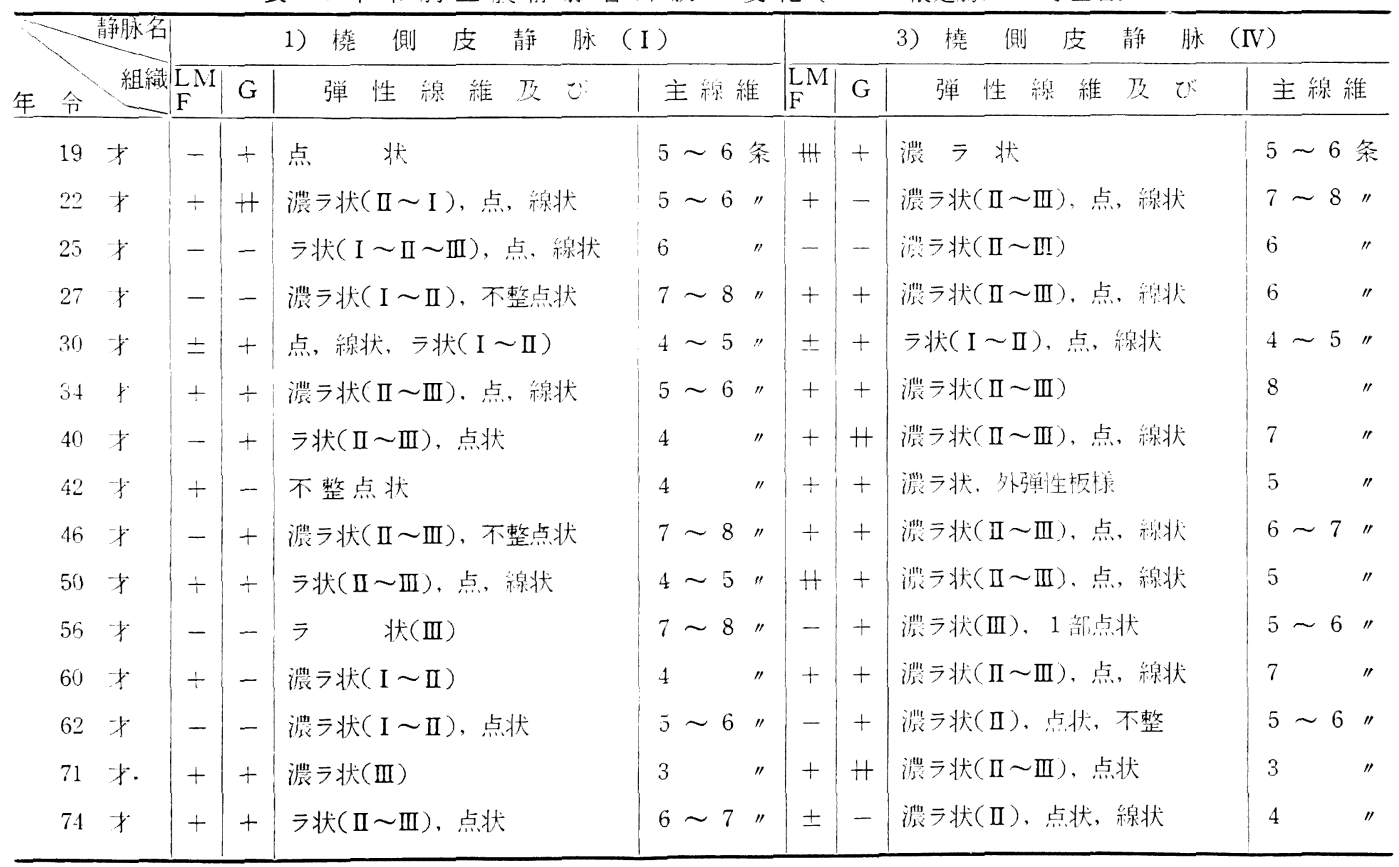




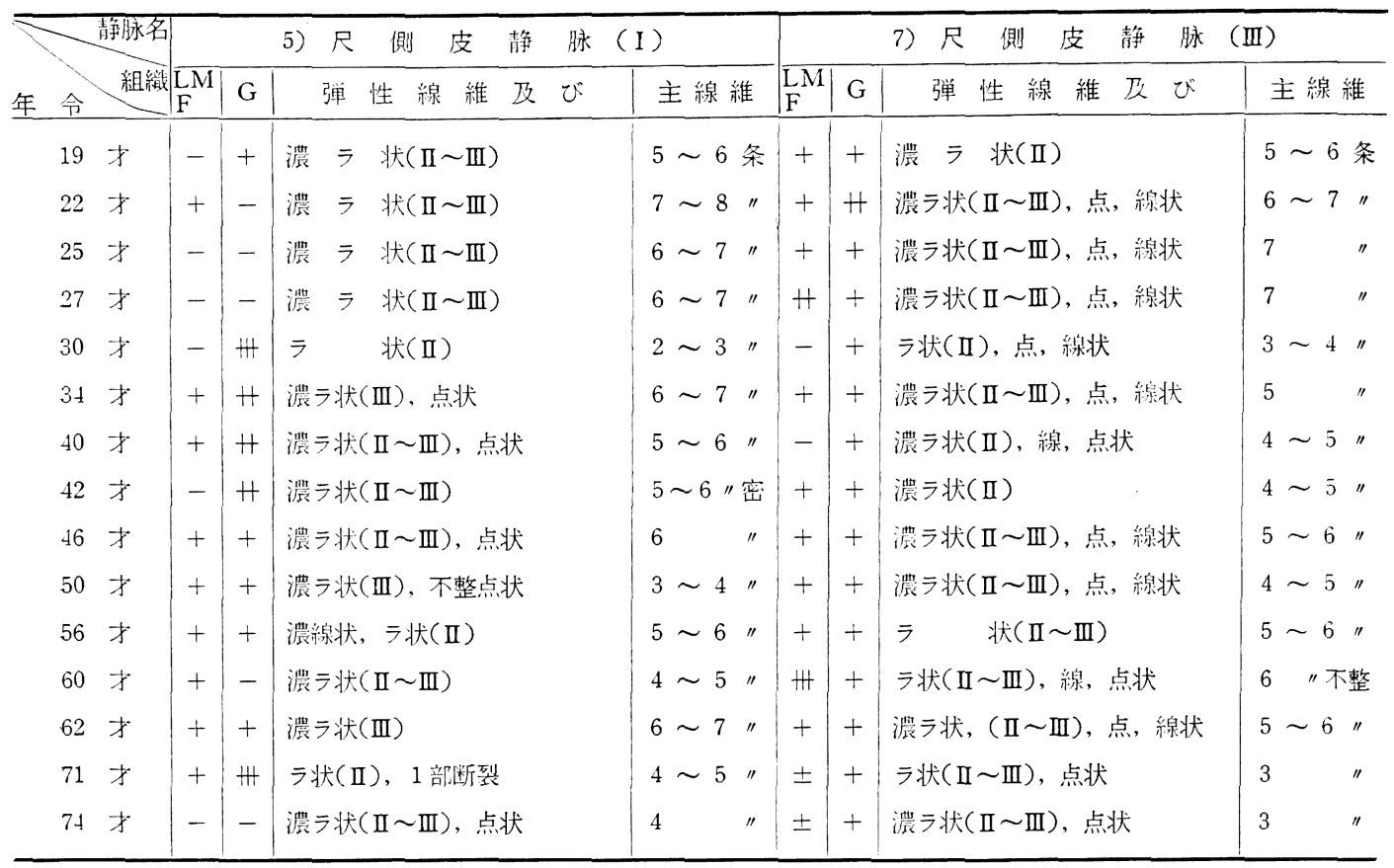

\begin{tabular}{|c|c|c|c|c|c|c|c|c|c|}
\hline \multirow{2}{*}{\multicolumn{2}{|c|}{ 年 }} & \multicolumn{4}{|c|}{ 12）固 有 背 側 指 静 脉 } & \multicolumn{4}{|c|}{ 13）上腕動脉伴行静脉（上） } \\
\hline & & $\begin{array}{l}\mathrm{LM} \\
\mathrm{F}\end{array}$ & G & 弾性線 維 及び & 主線維 & $\begin{array}{l}\mathrm{LM} \\
\mathrm{F}\end{array}$ & G & 弾 性 線 維 及び & 主線維 \\
\hline 19 & 才 & - & - & 濃 ラ 状 & 条 & - & - & 濃ラ状( I 〜 II) & $4 \sim 5$ 条柾 \\
\hline 22 & 才 & - & - & 濃ラ状 $(I \sim \Pi)$, 点状 & 4 & + & + & ラ状 (II), 大点状, 不整 & $4 \sim 5$ "柾 \\
\hline 25 & 才 & - & - & 濃ラ状 $(I \sim \Pi)$, 点, 楾状 & 4 & + & + & 大点状， ラ状 $(\mathrm{II} \sim \mathrm{III})$ & $7 \sim 8 \prime \prime$ \\
\hline 27 & 才 & - & - & ラ状 $(\mathrm{I} \sim \mathrm{II})$, 点, 線状 & 5 "不整 & + & - & 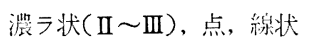 & \\
\hline 30 & 才 & - & \pm & 厏ラ状( I ) & $4 \sim 5 \prime \prime$ & + & - & 浱ラ状, 短線, ラ状 $(\mathrm{I} \sim \mathrm{II})$ & $5 \sim 6 "$ \\
\hline 34 & 才 & - & - & 濃ラ状 $(\mathrm{I} \sim \mathrm{II} \sim \mathrm{III})$, 細点状 & $4 \sim 5 \prime \prime$ & + & + & 濃大線, 点状, ラ状 (I) & 6 \\
\hline 40 & 才 & - & - & 濃ラ状 $(\mathrm{I} \sim \mathrm{II} \sim \mathrm{III})$, 点状 & $4 \sim 5 \prime \prime$ & - & - & 浱ラ状 $(\mathrm{I} \sim \mathrm{II})$, 大線, 点状 & $5 \sim 6$ \\
\hline 42 & 才 & + & + & 濃ラ状 $(I \sim I I)$, 不整 & $4 \sim 5 \prime \prime$ & + & - & 濃ラ状 (II〜III), 線, 点状 & 6 \\
\hline 46 & 才 & + & - & 濃ラ状 $(\mathrm{II} \sim \mathrm{III})$, 点, 線状 & & - & - & 湍点, 線状, 不整 & $5 \sim 6 "$ \\
\hline 50 & 子 & - & - & 浱ラ状 $(\mathbb{I} \sim \mathrm{II})$, 点, 線状 & $5 \sim 6 "$ & + & + & 大点状, 線状 & $5 \sim 6 "$ \\
\hline 56 & 才 & + & - & 浱ラ状 $($ II 〜 III $)$, 点, 線状 & $4 \sim 5 \prime \prime$ & - & + & 濃ラ状( II ) & $3 \sim 4 "$ \\
\hline 60 & 才 & + & - & 細浱ラ状 (II), 線, 点状 & $4 \sim 5 \prime \prime$ & + & - & ラ状 $(I I \sim m)$, 点状 & 3 \\
\hline 62 & 才 & + & - & 沄ラ状 $($ II〜III), 点, 線状 & $4 \sim 5 \prime \prime$ & - & + & 浱染中, 大, 点状 & $7 \sim 8 \prime$ \\
\hline 71 & 才 & + & + & ラ状 (II 〜III), 点状 & 3 " 疎 & + & H & ラ状 $(\mathrm{II} \sim \mathrm{III})$, 点, 線状 & $4 \sim 5 "$ \\
\hline 74 & 才 & - & - & 細濃ラ状 $(I \sim I I)$, 点状 & $4 \sim 5 \prime \prime$ & $H$ & + & 濃ラ状 (II), 点, 線状, 不整 & " 柾 \\
\hline
\end{tabular}




\begin{tabular}{|c|c|c|c|c|c|c|c|c|c|c|}
\hline & & 静脉 & & & 19) 橈骨動脉伴行静脉 & (上) & & & 23）尺骨動脉伴行静脉 & （上） \\
\hline 年 & 令 & 組織 & $\begin{array}{l}\overline{\mathrm{LM}} \\
\mathrm{IF}\end{array}$ & G & 弾性線 維 及び & 主線維 & $|\overline{\mathrm{LM}}|$ & G & 弾 性 線 維 及 び & 主線維 \\
\hline & 19 & 才 & - & + & 搌ラ状( I 〜 II ) & $4 \sim 5$ 条 & - & - & 濃 ラ 状 & $4 \sim 5$ 条 \\
\hline & 22 & 才 & + & - & 濃ラ状 $(I \sim \Pi)$, 点状 & $4 \sim 5 n$ & + & - & 㳪亏状 $(I \sim \Pi)$, 点状 & $3 \sim 4 \prime$ \\
\hline & 25 & 才 & H & + & 濃ラ状 $(\mathrm{I} \sim \mathrm{II})$, 点, 線状 & & + & - & 源ラ状( I 〜 II), 点状 & 4 \\
\hline & 27 & 才 & - & - & 浱ラ状 $(\mathrm{I} \sim \mathrm{I})$, 点, 線状 & $3 \sim 4 n$ & - & - & 濃ラ状 $(\mathrm{I} \sim \mathrm{II} \sim \mathrm{III})$, 大点, 線状 & $6 \sim 7 "$ \\
\hline & 30 & 才 & - & - & 濃点, 線状, ラ状 ( I ) & $3 \sim 4 n$ & - & - & 浱点状, 線状 & 4 \\
\hline & 34 & 才 & - & - & 濃点, 線状, ラ状 ( I ) & & - & - & 濃ラ状 $(\mathrm{I} \sim \mathrm{I} \sim \mathrm{II})$, 点, 線状 & 6 \\
\hline & 40 & 才 & - & - & 濃点, ラ状 (I), 線状 & $4 \sim 5 \prime \prime$ & - & - & 溫ラ状 (I), 点, 線状 & 3 \\
\hline & 42 & 才 & H & - & 濃ラ状( II～III) & 7 & - & - & 線状, ラ状 & $4 \sim 5 \pi$ \\
\hline & 46 & 才 & - & + & 浱短ラ状 $(\mathrm{II} \sim \mathrm{II})$, 点, 線状 & 5 & + & - & 点状, 濃ラ状 $(I ＼sim I)$ & 4 \\
\hline & 50 & 才 & + & + & 浱ラ状 $(I 〜 I I)$, 中点, 短線 & $4 \sim 5 \prime \prime$ & + & - & 源ラ状 $(I I \sim I I)$, 点, 線状 & $7 \sim 8 "$ \\
\hline & 56 & 才 & + & + & ラ 状(II) & 3 & - & + & 浱ラ状(III). 点状 & $5 \sim 6 "$ \\
\hline & 60 & 或 & - & - & ラ状(II), 中点, 短線状 & & + & - & 濃ラ状 $(\mathrm{I} \sim \mathrm{II} \sim \mathrm{III})$, 点, 線状 & $5 \sim 6 "$ \\
\hline & 62 & 才 & + & - & 濃ラ状(II), 迺続 & 外弹性板样 & + & $H$ & 浱ラ状( II～III), 点, 線状 & $4 \sim 5 \prime \prime$ \\
\hline & 71 & 才 & + & H & 濃ラ状 $(I I 〜 I I I)$, 不正点状 & & + & + & ラ状 $($ II 〜III), 点状 & $4 \sim 5 \prime \prime$ \\
\hline & 74 & 才 & - & - & 濃ラ状 (II), 点, 短線状 & $3 n$ 不整 & - & - & 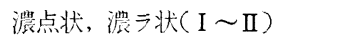 & " 柾 \\
\hline
\end{tabular}

$(\div の 5)$

\begin{tabular}{|c|c|c|c|c|c|c|c|c|c|c|c|c|}
\hline \multirow[b]{2}{*}{ 年 } & & 静脉名 & \multicolumn{5}{|c|}{ 29）线 掌 静 脉 弓 } & \multicolumn{5}{|c|}{ 35）固有掌 側指 静 脉 } \\
\hline & 令 & 組織 & $\mathrm{LM}$ & G & 弾 性 線 維 及 び & 主線約 & & \begin{tabular}{|l|l|l|l|}
$\mathrm{LM}$ \\
\end{tabular} & G & 弾 性線維 及び & 主線維 & \\
\hline & 19 & 才 & - & - & 搌ラ状( I 〜 II ) & 3 & 条 & - & - & 濃ラ状 $(\mathrm{I} \sim \mathrm{II})$, 点状 & & \\
\hline & 22 & $才$ & - & - & 濃点状, 短ラ状 (II) & 3 & $"$ & - & - & 濃ラ状 $(\mathrm{I} \sim \mathrm{II})$, 点, 線状 & $2 \sim 3$ & \\
\hline & 25 & 才 & - & - & 濃ラ状 $(I \sim I I)$, 点, 線状 & 2 & $"$ & - & - & 濃ラ状 $(I \sim \Pi)$, 点, 線状 & 2 & $"$ \\
\hline & 27 & 才 & - & - & ラ状 $(\mathrm{I} \sim \mathrm{II})$, 濃点, 線状 & $2 \sim 3$ & $"$ & - & - & 摆ラ状( I 〜 II ), 点状 & 2 & $"$ " \\
\hline & 30 & 才 & - & - & 眦ラ状( I 〜 II), 点状 & 2 & $"$ & - & - & 短湡ラ状 $(\mathrm{II} \sim \mathrm{III})$, 点状 & $2 \sim 3$ & $" \prime$ \\
\hline & 34 & 才 & - & - & 裖ラ状( I 〜II) & 2 & $"$ & - & - & 浱ラ状( I 〜 II) & $2 \sim 3$ & $"$ \\
\hline & 40 & 才 & - & - & 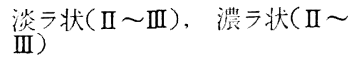 & 3 & " & - & - & 源ラ状( II)，点状 & $2 \sim 3$ & \\
\hline & 42 & 才 & - & - & ラ $\quad$ 状 $($ III $)$ & $2 \sim 3$ & " & - & - & 短濃ラ状( II 〜III)、点状 & $2 \sim 3$ & $" r$ \\
\hline & 46 & 才 & - & - & 嶩短亏状 $(\mathrm{I} \sim$ II $)$, 短線状 & $3 \sim 4$ & $n$ & - & - & 短濃亏状 $(\mathrm{II} \sim \mathrm{III})$, 点, 短線状 & $2 \sim 3$ & $"$ - \\
\hline & 50 & x & - & - & 浱ラ状( I 〜 II), 点状 & $2 \sim 3$ & $n$ & - & - & 短ラ状 (II 〜III), 点状 & $2 \sim 3$ & $"$ \\
\hline & 56 & 才 & - & - & 浱ラ状( I 〜II), 点状 & $3 \sim 4$ & $"$ & - & - & 短潈ラ状 $(\Pi \sim \mathrm{II})$, 点状 & $2 \sim 3$ & $"$ \\
\hline & 60 & 才 & + & - & 嶩中, 大点状, 短線状 & $2 \sim 3$ & $"$ & - & - & 短浱ラ状( II 〜II)，点状 & $2 \sim 3$ & $"$ \\
\hline & 62 & x & - & - & 濃ラ状 $(I 〜 I I)$, 短線, 点状 & $2 \sim 3$ & $"$ & - & - & 短淈ラ状 $($ II 〜III). 短線状 & $2 \sim 3$ & \\
\hline & 71 & 才 & - & - & ラ状 $(\mathrm{I} \sim \mathrm{II})$, 点状 & 偘 少 & " & - & - & 短ラ状 $($ II 〜III $)$, 点状 & 2 条 1 & 位 \\
\hline & 74 & x & - & - & 濃短ラ状 $(I \sim \Pi)$, 小点状 & 3 & " & - & - & ラ状( I 〜 II ), 点状 & & 少 \\
\hline
\end{tabular}

則かつ強く波行 (ラ状III) 中膜周辺部に密である（内 縋走筋同様特に外往走筋刍腕関節部附近皮下静脉に多 く認められる)。
山本, 石田の報告にも見られる通り，尺㑡皮·橈骨・ 背側指. 各静脉では輸走傾向が強く, 背側中手では

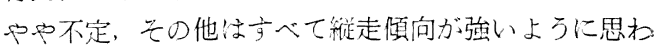


れる。縦走筋のある所は筋の周囲汇細点状の $\mathrm{EF}$ が認 められる。な拉, 年令的変化に関しては動脉管の報告 にあるが如き確然たるものは認められざるも中膜同様 $\mathrm{EF}$ は，30 才頃までは増加の傾向あり，60台までは 変化老認心がたきも，70才を過ると線維も短かくラ状 も細く，小さく，焱染し踈となる傾向を示している。

以下個々の成績につき拔粋せるものを表 11 亿掲げ る。

\section{総括並びに結論}

著者は一定条件下に固定せる 19 才より 76 才に至 る本邦人居 45 体（男 35 , 女 10) 飞つき, 皮下 18 , 深静脉 40 部位を七ロイジン包埋後, $15 \mu$ の切片と し，ヘマトキシリン・エオジン染色及びワイゲルト弾 性線維染色並泟無染色標本を作製し, 主としてミク口 メーターに上り上肢静脉の内径, 壁厚を計測し, 併せ て产の組織学的構造並ひに年令的組織的変化を観察し た。その成績は，概ね下記の如くである。

1. 上肢静脉管の内径の平均値及び最大, 最小値は 表 2 亿示す如くであり，内径は各静脉とも末梢方より 中心方に進むにしたがい增大する傾向がある。

2. 各人生期別上肢静脉管の内径情 3 に示寸如く で，動脉注ど著明ではないが，加令とともに潮增する 傾向の認められるものが多い。

3. 上肢静脉管壁厚の平均值及び最大, 最小值は表 2 亿示寸如くで, 壁厚の大小は概して内径の大きさに 平行するものが多い。

4. 各人生期別静脉の壁厚性表 4, 表 5 亿示す如く である。皮下静脉に括いては著明な変化を認めない が，深静脉に括いては，第一老年期まて漸增し第二老 年期より堿ずる傾向の見られるものが多い。

5. 上肢静脉管の厚度率の平均值は表 2 飞示す如く で，末梢方上り中心方に向つて厚度率小となり，また 皮下静脉上り深部静脉の方が厚度率小となる。

6. 各人生期別厚度率は表 2 に示寸如くで, 第二老 年期に㨟いて小となる傾向の外は著明な変化は認めが たい。

7. 個体別に上る左右の比較を行えば表 7 に示寸如 くで, 皮静脉に招いては, 内径は右〉左, 厚径は左 右と相半ばし，厚度率はさしろ左>右のものが多く, 深静脉儿括いては, 内径注右左, 厚径は左 $\doteqdot$ 右, 厚 度率は左＼cjkstart右であるものが多い。

8. 暁. 尺両動脉に伴行する静脉の数は表 8 亿示す 如くで，男性に括いて左有の別なく尺側の方が多い。

9 . 上肢静脉管の内膜 -中膜 - 外膜の壁厚の平均值
は表 9 に示す如くで，各層とも（特に皮下静脉内膜に 著明) 时・腕両関節部附近飞未いて数值の增大を示 乙, 深静脉は皮静脉に比較し, 各層とも幾分薄く, ま た中・外膜の比率が中心方は皮下静脉同様 $1: 2$ なる も末梢方は皮下静脉 $2: 3$ 亿対し 1 亿近い。

10. 各人生期別上肢静脉管の内 - 中 - 外膜各凰の平 均値は, 表 10 に示す如くで, 内膜の傾向は不著明な るも中膜愉第四成熟期. 第一老年期まで漸增し, 第二 老年期より減ずる傾向にあり．外膜もほよ゙これに準ず る。

11. 上肢静脉管内膜の年令的組織学的変化は, 動脉 管の如き確然たるもの㤘認められないが，内綎走筋の 出現率は, 先人の報告上り幾分頻度が高い上うに思わ れる。

12. 上肢静脉管中膜の年令的組織学的変化老, 表 11 に示す。中膜经主として輪走筋よりなり，その間弾性 線維が部位により縦走. 輪走の割合を異にして走り (主として縦走), 年令的には30才頃まで増加し, そ の後ふ著変なく，70 才を過ぎると楾維も短かく染染 し細くなり, ラ状も小さく疎となるように思われる。

13.上肢静脉管外膜の年令的組織学的変化を表 12 に示す。弾性線維は 3 膜中最子粗大江波行し, 中膜周 辺部に特に密である。周囲の結合組織とは蹯なる点状 の弹性線維となり移行する。年令的変化は中膜に準ず る。

14. 全例在通じ肘. 腕関節部附近 (特江肘関節) 静脈 にが゙り, 内・中・外 3 膜壁厚の増大あり, 就中, 内 外縦走筋の多数出現することは屈曲時の物理的外力に 対する血行維持のための補䏚ならんか上思考される。

15. 上肢動静脉の年令的変化を比輍要約すると, 動 脉り変化は内膜において著しく, 而も来梢方より29才 頃から部分的增殖を来し, 40 才以後に汶大多数肥厚, 70 才においては明らかな硬変を全域に認める(今井)に対 し，静脉のそ机は各層共きわめて緩徐であり，末梢方 中心方の差異导热めがたく弾性線維の消長より見れば 線維洨, 30 才頃まで增加しその後注著変なく(幾分下降 ：）70才を過ると比較的明らかに質量共変化を認める。 上記の成績恃著者の限られた資料に基つくため, そ の結果が個人の解剖学的, 生理学的関係その他により 相違を来たすべきことは勿論のととと思惟する

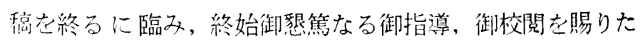
る恩師金子丑之助教授に二深甚の謝意を捧壮ると共に，種々御 教示を頂いた清水, 高石, 吉川 3 博士に深く感謝を捧牧, ま た一方なら放御協力を戴いた寺山医学士に謝意を表する。 


\section{佐伯論文附図}

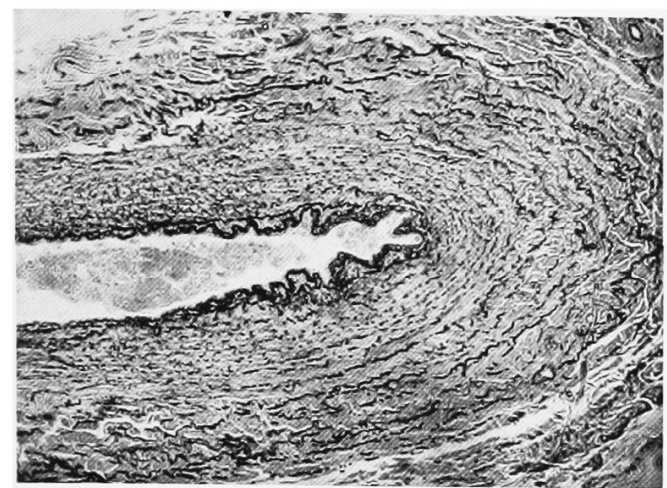

1）19才合 橈側寺棦永（VI）ワイデルト

E. F. 染色（內．中．外膜と

屯 E. F。著明)

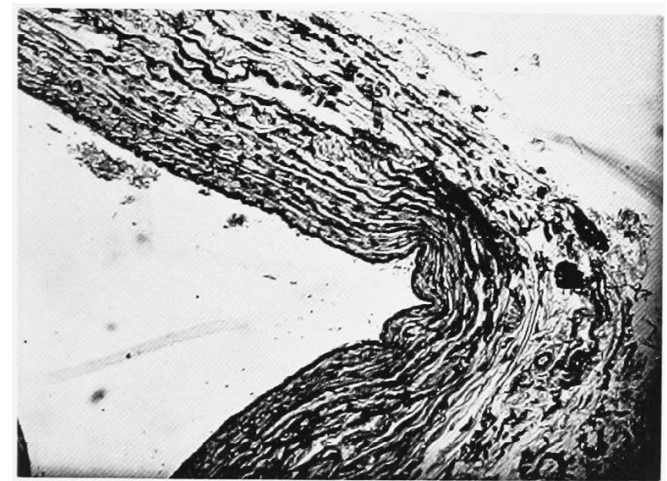

3) 50 千古 尺側氐㬹膜 (VI) ワイゲルト

E. F。舞色(各層濃染L E .

F。な著明)

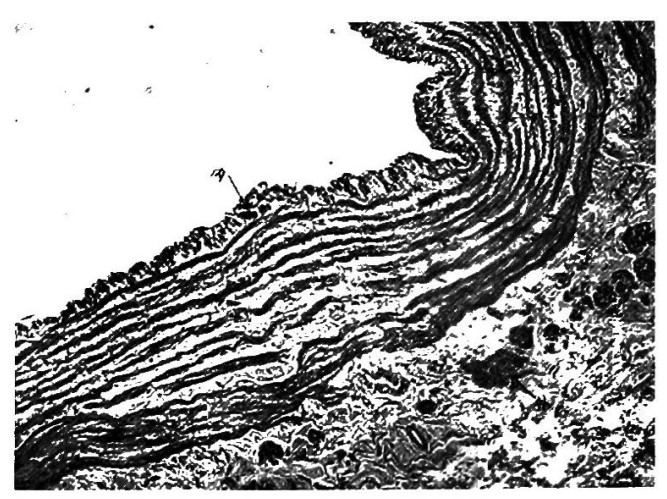

5 ） 60 才 今 尺側皮䈋永（III） H. E. (染色內, 外縱走筋 (矢印) を認める)

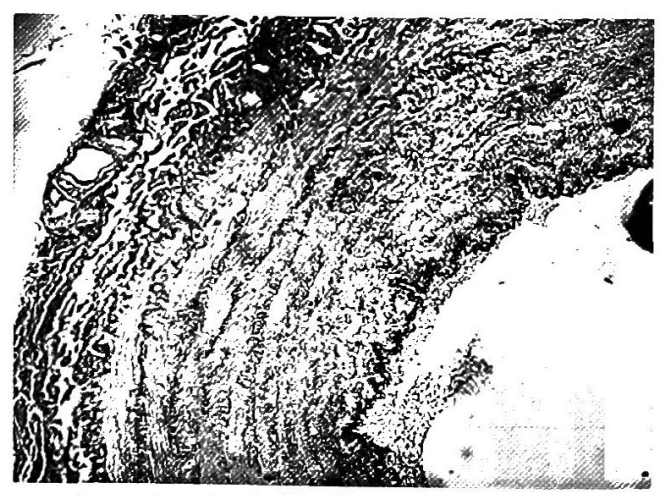

2) 30 才。 暁側皮嫯脉 (VI) ワイゲルト E. F. 染色 (1より增加の 傾向あり)

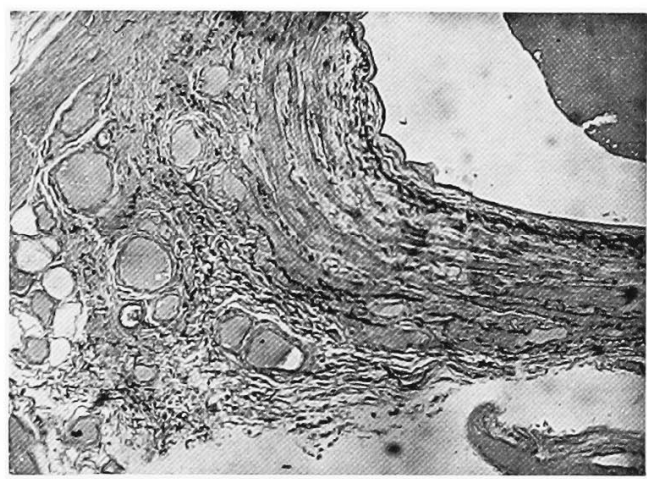

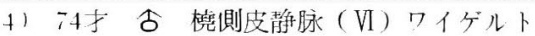
E. F . 染色 (內. 中. 外膜質 量とも E. F . 变化減少する)

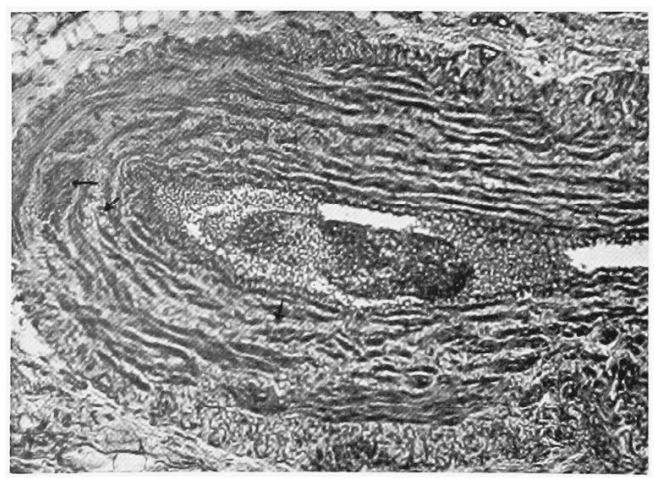

6) 61才 今 暁側皮静脉 (I) H. E. 染色 (中膜內縱走筋 (矢印) を認める) 


\section{主 要 文 献}

1）山下兼澄: 九州日本人静脉管壁の計測, 四肢皮静脉, 熊本医誌, 12, 1123 (1936)

2）山下兼澄：九州日本人静脉管壁の計測，四肢深静脉 熊本医誌, 12, 1179 (1936)

3）菘本 清：日本人体皮下静脉（生体），軍医団䧱誌， 274, 140 (1934)

4）渡辺俊男：静脉の組織棈造の血行について，日本生理 誌, 12, 135 (1950)

5）湾辺俊男: 静脉の螨造と機能, 日本生理誌, 13,93 (1951)

6）渡辺拨男: 静脉壁の有可弾力線維, 压島医学誌, 3 , 136 (1950)

7）渡辺俊男：静脉の蔧造と分類について，広島医学誌， 2, 234 (1949)

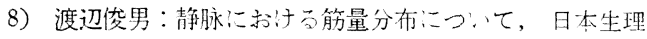
誌. 11，249 (1949)

9）渡辺邆男：静脉の伸展性沪就、て, 日本生理誌, 12, 84 (1950)

10）吉中豊久：血管の受動的収宿性汇ついて, 広島医学誌 2, 116 (1949)

11）山本 弘：全身血管系: 污方格子線維，鳥取大学解 剖学教室業績集，1 85，161（1954）

12）西田却彦：成人に古门万静脉壁笳量分布, 熊本医学誌, 28, 1184 (1954)

13）藤田為刀：人の諸動脉, 静脉壁の成分比皎研究, 日本 組織学記録, 3，183 (1952)

14) 石田 守: 人の静脉壁の弾性楾維, 解剖学䧱誌, 35, 127 (1960)

15）金子丑之助：日本人体解窝。学，I，II，III（1957）

16）金子丑去助：最新組織学, (1957)

17）今井良一：本邦人上肢動䐂管についての一, 二の計測 之云の組織学的惯造, 日医大誌, 20, 277 (1953)

$$
\text { (1599) }-157-
$$

18）海老沢朵彦：上肢筋線倠間動脉の年令的变化，日医大 誌, 25, 999 (1958)

19）古屋芳雄, 宮坂五一郎：医学統計法附小数統計法, (1956)

20）押見賢一：血管弾力線維の性状について, 北海道医誌, 12, 1553 (1934)

21) Bennighoff. A : Blutgefässe und Herz.Möllendorffs Handbuch d. mikr. Anatom. d. Mensehen. VI (133), 150 (1930)

22) Fanklin, K.J. : A monograph on veins, $35 \sim 63$ (1937)

23) Görttler, K. : Die funktionelle Bedeutung des Baues der Gefässwand, 170 443 (1953)

24) Hochlein, M!. u. Singer. $\beta$. : Untersuchungen am venösen Teil des Kreislaufes, II. Mitteilung; Untersuchungen über den Bau der Venenwand 125, 301 (1927)

25) Kugelgen, A. : Über den Wandbau der Gros. venen, Morphol. Jb., 91, 447 (1951)

26) Arnold: Handbuch d. Anatomie d. Menschen, II (1851)

27) Gegenbaur: Anatomie d. Menschen II.

28) Henle: Systematische Anatomie d. Menschen,

29) Krause: Spezielle u. makroskopische Anatomie (1879)

30) Voss, Herman : Grundriss der normalen Histologie u. mikroskopischen Anatomie 8, Verb. Aufl. Leipzig (1955)

31) Watzku, Max: Kurzlehrbuch der Histologie u. mikroskopischen Anatomie des Menschen, Stut. tgart (1957)

七の他 